\title{
Mineral Assemblage Transformation of a Metakaolin-based Waste Form After Geopolymer Encapsulation
}

\section{Authors}

Benjamin D. Williams ${ }^{1 *}$, James J. Neeway ${ }^{1}$, Michelle M. V. Snyder ${ }^{1}$, Mark E. Bowden ${ }^{1}$, James E. Amonette ${ }^{1}$, Bruce W. Arey ${ }^{1}$, Eric M. Pierce ${ }^{2}$, Christopher F. Brown ${ }^{1}$, and Nikolla P. Qafoku ${ }^{1}$

\section{Affiliations}

1. Pacific Northwest National Laboratory, PO Box 999, MSIN P7-54, Richland, WA 99352 USA; Benjamin.Williams@pnnl.gov, James.Neeway@pnnl.gov, Michelle.ValentaSnyder@pnnl.gov, Mark.Bowden@pnnl.gov,Jim.Amonette@pnnl.gov, Bruce.Arey@pnnl.gov, Christopher.Brown@pnnl.gov, Nik.Qafoku@pnnl.gov

2. Oak Ridge National Laboratory, PO Box 2008, MS-6035, Room 372, Oak Ridge, TN 37831, USA; pierceem@ornl.gov

\section{Corresponding Author}

*Benjamin D. Williams, Pacific Northwest National Laboratory, PO Box 999, MSIN P7-54, Richland, WA 99352 USA; Benjamin.Williams@pnnl.gov

\section{$\underline{\text { Abstract }}$}

Mitigation of hazardous and radioactive waste can be improved through conversion of existing waste to a more chemically stable and physically robust waste form. One option for waste conversion is the fluidized bed steam reforming (FBSR) process. The resulting FBSR granular material was encapsulated in a geopolymer matrix referred to here as Geo-7. This provides mechanical strength for ease in transport and disposal. However, it is necessary to understand the phase assemblage evolution as a result of geopolymer encapsulation. In this study, we examine the mineral assemblages formed during the synthesis of the multiphase ceramic waste form. The FBSR granular samples were created from waste simulant that was chemically adjusted to resemble Hanford tank waste. Another set of samples was created using Savannah River Site Tank 50 waste simulant in order to mimic a blend of waste collected from 68 Hanford tank. Waste form performance tests were conducted using the product consistency test (PCT), the Toxicity Characteristic Leaching Procedure (TCLP), and the single-pass flow-through (SPFT) test. X-ray diffraction analyses revealed the structure of a previously unreported NAS phase and indicate that monolith creation may lead to a reduction in crystallinity as compared to the primary FBSR granular product. 


\section{$\underline{\text { Keywords }}$}

- Low-Activity Waste

- Fluidized Bed Steam Reformer

- Feldspathoid minerals

- Waste form leach test 


\section{$\underline{1.0 \text { Introduction }}$}

The ability to predict the behavior of waste forms (e.g., mineral and glass) over geological time scales constitutes one of the main scientific challenges for evaluating the long-term impacts of nuclear waste storage on public health and environmental resources [1,2]. Hazard mitigation can be improved through conversion of existing waste to a more chemically stable and physically robust waste form. Current research favors waste encapsulation through vitrification or incorporation into cementitious or ceramic matrices $[1,4,5]$. One example of conversion of hazardous or radioactive waste into a more stable ceramic waste form is the fluidized bed steam reformation (FBSR) process that produces a multiphase sodium aluminosilicate (NAS) ceramic material from high-sodium waste streams [6]. In order to increase the mechanical strength of the waste form and to facilitate transportation and disposal, a monolith can be formed by combination of the FBSR granular product with an encapsulating material that binds the granular product in a largely inert chemical matrix. One such material with a possibility to serve as a binder of the radioactive FBSR product is a geopolymer.

Ceramic waste forms have been studied extensively as a potential host matrix for radionuclides $[7,8,9,10]$. Some of the most studied multiphase waste forms include SYNthetic ROCk (SYNROC) [11], tailored ceramics [12], pyrochlore [13,14], zirconolite [15,16], and glass-ceramics [17]. For an overview of the these multiphase waste forms see the reviews by Lutze and Ewing [18], Lee et al. [19], Caurant et al. [20], and the NRC [21]. Improving the scientific and technical basis for using multiphase ceramic waste forms in nuclear waste management requires an understanding of the speciation, partitioning, and the release behavior of radionuclides immobilized in the multiphase matrix.

Geopolymers are formed by interaction of solid aluminosilicate minerals with aqueous alkali silicate or hydroxide solutions. Along with previous investigations of geopolymer use in toxic and radioactive 
waste immobilization [22,23,24,25], geopolymer materials have recently been the subject of many scientific investigations due to their use in several applications including refractory materials [26], biotechnologies [27], and cements [28,29]. Geopolymers tend to be X-ray amorphous [30] but contain significant microstructure that varies depending on chemical content such as the $\mathrm{Si} / \mathrm{Al}$ ratio $[31,32]$. Geopolymer encapsulation suitability is favorable with respect to high $\mathrm{pH}$ conditions, relative impermeability, and thermal stability [33,34,35]. Geopolymers can be used for encapsulation of the FBSR granular material, but the phase assemblage evolution as a result of this encapsulation process must be understood to ensure that encapsulation in the geopolymer does not affect the chemical durability of the FBSR product.

In this study, we examine the mineral assemblages formed during the synthesis of the FBSR NAS multiphase ceramic waste form. The objective of the results discussed in this manuscript was to (1) determine the change in mineral assemblages that occur from encapsulating the FBSR NAS granular particles in a geopolymer matrix and (2) the impact of the monolith creation process on the chemical durability of the FBSR NAS material. Information on other characterization and performance testing can be found

\subsection{Materials and Methods}

\section{$\underline{2.1 \text { Sample Preparation }}$}

\subsubsection{Steam Reforming for Fabrication of Granular Material}

Granular samples were synthesized with engineering- and bench-scale steam reformers. Production of the engineering-scale granular sample was carried out at Hazen Research Inc. (HRI) in Denver, CO, USA using the THermal Organic Reduction $\left(\mathrm{THOR}^{\mathrm{SM}}\right.$ ) Treatment Technologies (TTT) Fluidized-Bed Steam Reformation (FBSR) process (www.thortt.com). The process operates by introducing a high-sodium liquid waste stream, which contains radioactive elements such as Tc, Cs, and I as well as other contaminants, into a fluidized bed where fluidization is maintained with superheated steam at near- 
ambient pressure. The waste that is introduced into the fluidized bed is reacted with carbon (coal), clay (kaolinite), and iron-based reductants at temperatures ranging from 650 to $800^{\circ} \mathrm{C}$. During the process nitrates and nitrites are converted to nitrogen gas, organic material is converted to $\mathrm{CO}_{2}$ and water, and a polycrystalline mineral product that encapsulates radionuclides, alkali metals, sulfate, chloride, fluoride, and non-volatile heavy metals is produced. Additional details are given elsewhere [36, 37, 38]. For this study, granular samples created with a non-radioactive simulant waste using the engineering-scale, THOR-TTT FBSR process are referred to as P1BG [37, 39].

The bench-scale steam reformed samples were created at the Savannah River Site (SRS) Bench-Scale Steam Reformer (BSR) with a simulant blend of 68 Hanford tank wastes known as the Rassat simulant [40]. In these samples Re is used as a surrogate for radioactive Tc. The operation of the BSR differs from that of the THOR-TTT FBSR process because the bed in the BSR is not fluidized due to geometric constraints dictated by construction of the BSR in a shielded cell at Savannah River National Laboratory. Construction in the shielded cell was necessary to carry out further tests with actual radioactive waste. Even without fluidization, the BSR process, like the FBSR process, destroys nitrates, nitrites and organic materials present in the waste and results in an alkali aluminosilicate mineral product containing radionuclides and other contaminants present in the initial waste. Previous tests have demonstrated that the lack of fluidization does not impact the gaseous or mineralizing reactions but only impacts particle growth [41] For this study, granular materials resulting from this process are referred to as BSRG.

\subsubsection{Fabrication of Geopolymer Containing Steam Reforming Granular Product}

Encapsulation of the granular product, in a geopolymer binder to form monoliths, was investigated as a means to prevent dispersion during transport and to add compressive strength to the potential final waste form. The choice of the geopolymer as binding material was made after testing various cements, hydroceramics, Ceramicrete, and geopolymers and their effects on the release of Cs, I, Re, S, and $\mathrm{Na}$ in 7day leach tests at $90{ }^{\circ} \mathrm{C}$ [42] Geopolymers have an amorphous cross-linked three-dimensional structure and remain amorphous because of insufficient water to crystallize into phases such as zeolites. 
For the P1B granular FBSR product and the BSR granular product, geopolymers were made by mixing the granular product and Class F fly ash with a $65 \%$ dry basis waste loading based on the mass of the granular product $[43,44]$. The granular product and Class F fly ash were combined in the mixing bowl of a planetary mixer and this was followed by the addition of a sodium silicate solution $(44.1 \mathrm{wt} \%$ $\mathrm{Na}_{2} \mathrm{O} \bullet \mathrm{SiO}_{2}$ ). After incorporation of the sodium silicate into the dry powder, a $50 \mathrm{wt} \% \mathrm{NaOH}$ solution was added with continual mixing. Water was added ( $\sim 15 \mathrm{wt} \%$ of the total mass of the mixture) and a paste was created. After about one minute of total mixing, the paste was transferred into two plastic cylinders, which were capped and left to cure for 28 days at ambient conditions on a benchtop. The resulting geopolymer was known as Geo-7. This composition had undergone studies to optimize FBSR loading, TCLP testing, and compressive strength testing to determine its suitability as an FBSR granular product immobilization agent $[34,43]$.

2.2 Moisture Content, Coal Removal, Brunauer, Emmett, and Teller (BET) Surface Area Analysis and $\underline{\text { Microwave Digestion (MWD) }}$

The moisture content of sample P1BG was assessed using a 10 -gram aliquot dried at $105^{\circ} \mathrm{C}$ and cooled to ambient temperature at 24-hour intervals. This provided a dryness baseline for future sample preparation.

The moisture content sample was then analyzed for coal content by heating at $525^{\circ} \mathrm{C}$ for $1,2,8,24$, and 36 hours. Residual coal from granular product fabrication was determined through a subsequent loss on ignition test at $950^{\circ} \mathrm{C}$ for periods up to two hours.

BET samples were prepared by sieving to recover the +200 to -100 size fraction. Where material availability was insufficient, the +325 to -100 mesh size fraction was used. The sample was then washed with ethanol in order to remove any remaining fine particles and heated to remove residual process coal. The BET analysis was performed with a Quantachrome Autosorb using $\mathrm{N}_{2}$ adsorption. 
Microwave digestion was performed on an aliquot of the remainder from the coal removal test.

Approximately 0.1 grams of sample was placed in each digestion vessel along with $5 \mathrm{ml}$ of concentrated nitric acid, $2 \mathrm{ml}$ of concentrated hydrochloric acid, and $2 \mathrm{ml}$ of concentrated hydrofluoric acid. The digestion vessels were placed in a CEM MARS5 microwave and heated at $180^{\circ} \mathrm{C}$ for 60 minutes. The contents of the digestion vessels were transferred to centrifuge tubes, treated with 0.45 grams of boric acid and diluted to $20 \mathrm{ml}$ with DDI. Following dissolution of the boric acid, the contents of the centrifuge tubes were filtered using $0.45 \mu \mathrm{m}$ PVDF filters and submitted for chemical analysis by ICP-OES and ICP-MS (Table 2b).

\subsection{Leaching Tests}

Leach testing consisted of the ASTM C1285 Product Consistency Test (PCT) [45], the EPA test method 1311 known as the Toxicity Characteristic Leaching Procedure (TCLP) [46], and the ASTM C1662 Single-Pass Flow-Through Test (SPFT) [47].

The PCT-A was used as a guide with the only deviation being the use of polytetrafluoroethylene (Teflon) containers instead of stainless steel [45]. Briefly, the PCT-A method is a static test where the material of interest is reacted for seven days at $90{ }^{\circ} \mathrm{C}$ with a solid-to-solution ratio of $1: 10$ by mass.

The TCLP was performed on the granular sample materials as they were received. The monolith materials were ground up using an agate mortar and pestle then wet sieved with ethanol to obtain the $<74$ to $>149 \mu \mathrm{m}$ size fraction. Essentially, the TCLP is a short-term extraction performed at ambient temperature "to determine the mobility of both organic and inorganic analytes present in liquid, solid, and multiphasic wastes" [46]. 
Dynamic SPFT experiments were performed solely on the monolith materials, P1BM and BSRM. Results from the granular materials, P1B and BSR, are given elsewhere [48]. A schematic apparatus of the SPFT system is presented in Figure 1. All solutions were buffered at $\mathrm{pH} 9$ using $0.05 \mathrm{M}$ tris (hydroxymethyl) aminomethane (THAM) pH adjusted with $15.8 \mathrm{M} \mathrm{HNO}_{3}$. Steady-state was determined when successive effluent concentrations of the analyte of interest differed by less than $10 \%$.

Solutions obtained from the various tests were analyzed for $\mathrm{Na}, \mathrm{Si}$, and $\mathrm{Al}$ with Inductively Coupled Plasma-Optical Emission Spectroscopy (ICP-OES) and for Re, Cs, and I using Inductively Coupled Plasma-Mass Spectroscopy (ICP-MS). The anions $\mathrm{SO}_{4}{ }^{2-}, \mathrm{PO}_{4}{ }^{3-}, \mathrm{NO}_{3}{ }^{-}$, and $\mathrm{NO}_{2}{ }^{-}$were monitored using ion chromatography. However, after the first few sampling events, anion concentrations were below the detection limit and therefore the results are not reported in this paper. 


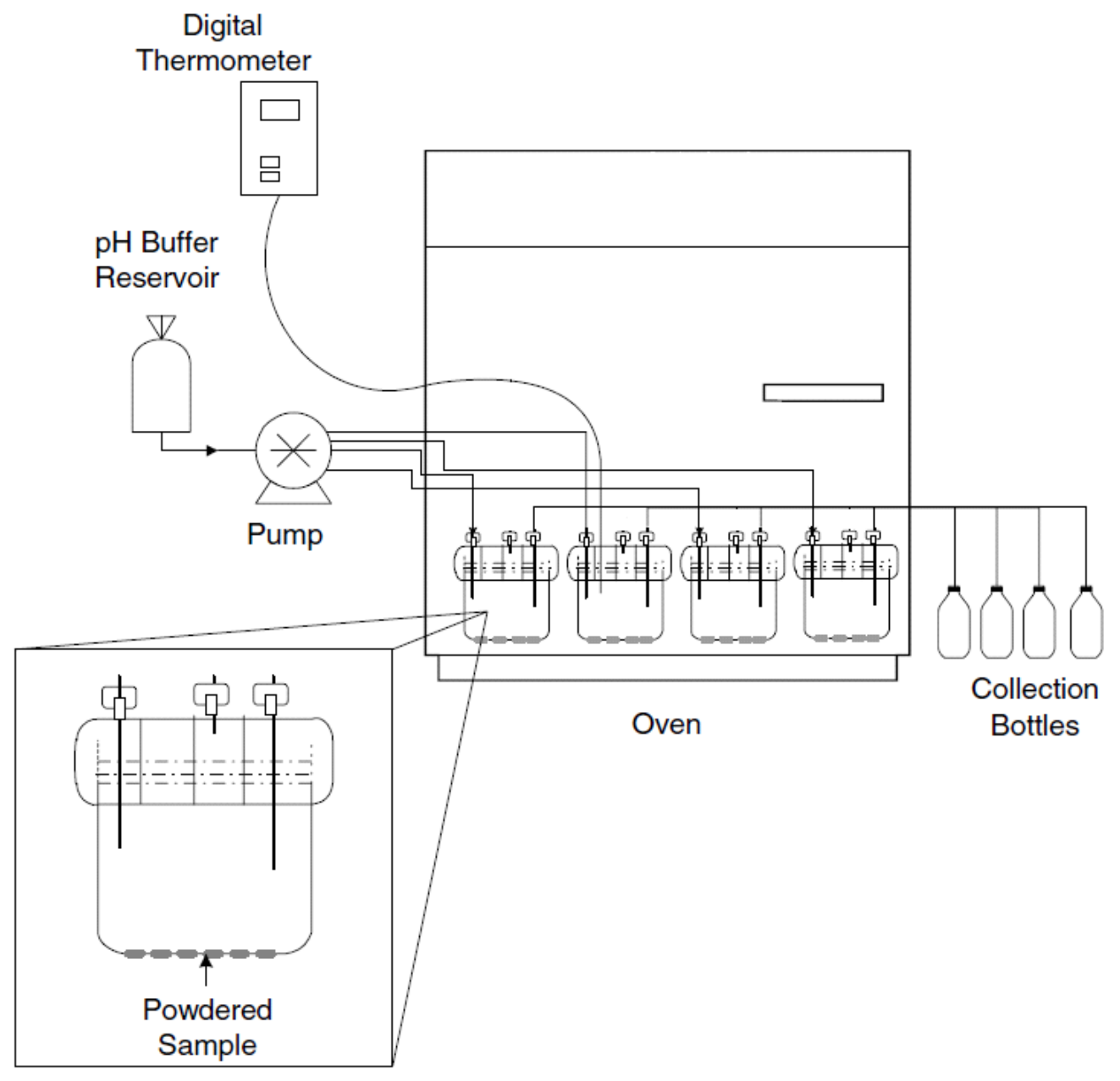

Figure 1. Schematic of the single-pass flow-through (SPFT) apparatus for determining reaction rates in continuous flow solution.

\section{$\underline{2.4 X-R a y ~ D i f f r a c t i o n}$}

All of the samples were suspected of containing substantial quantities of amorphous material. To estimate the quantity of amorphous material, a weighed amount of corundum $\left(\alpha-\mathrm{Al}_{2} \mathrm{O}_{3}\right.$, approximately 10 $\mathrm{wt} \%$ ) was mixed into each sample using a mortar and pestle. The specimens were loaded into traditional well-type aluminum holders with a cavity measuring $20 \times 15 \times 2 \mathrm{~mm}$. Powder diffraction data were collected with a Panalytical X'Pert Bragg-Brentano diffractometer using $\mathrm{Cu}-\mathrm{K} \alpha$ radiation $(\lambda=1.5418 \AA)$, 
a graphite post-diffraction monochromator, and variable divergence and anti-scatter slits (illuminated length $=10 \mathrm{~mm}$ ). Patterns were collected between 5 and $75^{\circ} 2 \theta$, counting for $2 \mathrm{~s}$ at $0.04^{\circ}$ steps.

Quantitative amounts of crystalline phases and amorphous material were estimated from Rietveld refinements [49] using the program TOPAS (v4.2, Bruker AXS). Crystal structures were obtained from the Inorganic Crystal Structure Database (Fachinformationszentrum Karlsruhe, Germany) and peak shapes were modelled using the fundamental parameters approach [50]. A new structure of $\mathrm{NaAlSiO}_{4}$ was identified and solved as described in the Supplementary Material. The known quantity of corundum added was used to place the quantities on an absolute scale and the estimate of amorphous material is then established from a difference calculation (i.e., the amount of "missing" material). Uncertainty in the estimates of phase proportions is approximately $+2 \%$ for each phase, based on the uncertainty reported by the refinement software and additional uncertainty arising from experimental considerations such as sample presentation and crystal perfection.

Initially, the ability of the method to quantify both crystalline and amorphous phases was tested on a known sample containing a mixture of zincite $(\mathrm{ZnO})$, rutile $\left(\mathrm{TiO}_{2}\right)$, eskolaite $\left(\mathrm{Cr}_{2} \mathrm{O}_{3}\right)$ and amorphous silica glass powder. The agreement between weighed and analyzed phase composition was excellent, with about 1 wt $\%$ accuracy.

\subsection{Scanning Electron Microscopy (SEM)/Energy-Dispersive X-ray spectroscopy (EDS)}

Scanning electron microscopy (SEM) aided by energy-dispersive X-ray spectroscopy (EDS) was used to investigate the nature of the "as received" P1BG and BSRG samples using an FEI Helios 600 NanoLab FIB-SEM. Operating conditions were typically $5 \mathrm{keV}$ or less for imaging and $20 \mathrm{keV}$ for EDS measurements. EDS spectra were collected using Oxford INCA software with a live count of 100 seconds with a typical dead time of $30 \%$. The P1BG sample was further investigated through preparation and scanning of several sites in a polished cross-section. Elemental mapping was applied to elucidate the distribution of elemental and physical characteristics. 


\section{$\underline{3.0 \text { Results }}$}

\subsection{Moisture Content and Coal Removal}

Moisture content and coal removal tests were performed on multiple aliquots of the P1BG material. Results shown in Table 1 represent total mass loss through the end of that time interval. P1BG moisture content yielded an average of $0.35 \pm 0.01 \%$ (Table 1 ). It can be inferred that any free water available on the granular surface is quickly removed within the first hour of heating.

P1BG coal removal test results are shown in Table 1. The data show that most of the coal is removed within the first hour of ignition; however, residual coal may remain in the sample and may require additional heating for complete removal. 
Table 1. Results from moisture content and coal removal test. Moisture content tests were performed at $105^{\circ} \mathrm{C}$ and coal removal tests were performed at $525^{\circ} \mathrm{C}$ for the indicated amount of time.

\begin{tabular}{llclc}
\hline $\begin{array}{c}\text { Duration } \\
\text { (hours) }\end{array}$ & $\begin{array}{c}\text { Moisture } \\
\text { Content } \\
\text { Sample ID }\end{array}$ & $\begin{array}{c}\text { Relative } \\
\text { weight } \\
\text { change }\end{array}$ & $\begin{array}{c}\text { Coal } \\
\text { Removal } \\
\text { Sample ID }\end{array}$ & $\begin{array}{c}\text { Relative } \\
\text { weight } \\
\text { change }\end{array}$ \\
\hline 1 & MC1 & $-0.35 \%$ & CR1 & $-1.45 \%$ \\
1 & MC2 & $-0.35 \%$ & CR2 & $-1.41 \%$ \\
2 & MC3 & $-0.35 \%$ & CR3 & $-1.58 \%$ \\
2 & MC4 & $-0.36 \%$ & CR4 & $-1.65 \%$ \\
8 & MC5 & $-0.35 \%$ & CR5 & $-1.67 \%$ \\
8 & MC6 & $-0.34 \%$ & CR6 & $-1.67 \%$ \\
24 & MC7 & $-0.36 \%$ & CR7 & $-1.72 \%$ \\
24 & MC8 & $-0.35 \%$ & CR8 & $-1.72 \%$ \\
36 & MC9 & $-0.37 \%$ & CR9 & $-1.98 \%$ \\
36 & MC10 & $-0.34 \%$ & CR10 & $-1.91 \%$ \\
36 & MC11 & $-0.34 \%$ & CR11 & $-1.90 \%$ \\
36 & MC12 & $-0.34 \%$ & CR12 & $-1.79 \%$ \\
\hline
\end{tabular}

\section{$\underline{3.2 \text { BET Surface Area }}$}

BET surface area for the four FBSR samples is shown in Table 2a. There was a wide variance in surface area between the monolithic and granular forms, suggesting that monolith production adds porosity. At this time, the reason for the difference in surface area for the monolithic and granular materials is unclear. One explanation is that the monolith samples contained coal and the presence of this material may have contributed to the increase in surface area. Additionally, measurements are also required to shed light on the reduced mass loss of the monolith as compared to the granular materials. 
Table 2a. Normalized mass loss (NL) values from the Product Consistency Test (PCT) for various elements present in the FBSR and BSR granular and monolith products.

\begin{tabular}{|c|c|c|c|c|c|c|c|}
\hline $\begin{array}{c}\text { P1B } \\
\text { granular } \\
\text { as } \\
\text { received }\end{array}$ & $\begin{array}{c}\text { P1B } \\
\text { granular } \\
\text { roasted }\end{array}$ & $\begin{array}{c}\text { P1B } \\
\text { monolith }\end{array}$ & $\begin{array}{c}\text { BSR } \\
\text { granular } \\
\text { as } \\
\text { received }\end{array}$ & $\begin{array}{c}\text { BSR B } \\
\text { granular } \\
\text { roasted }\end{array}$ & & & \\
\hline & & BET & 5.95 & 4.93 & 38.1 & 8.16 & 3.34 \\
\hline & & $\mathrm{pH}$ & $11.4 \pm 0.4$ & $11.8 \pm 0.1$ & $11.9 \pm 0.1$ & $10.1 \pm 0.6$ & $9.8 \pm 1$. \\
\hline & & $\mathbf{A l}\left(\mathrm{g} / \mathrm{m}^{2}\right)$ & $1.71 \times 10^{-}$ & $2.07 \times 10^{-}$ & $5.54 \times 10^{-}$ & $8.26 \times 10^{-4}$ & $9.47 \times 11$ \\
\hline & & $\operatorname{Re}\left(\mathrm{g} / \mathrm{m}^{2}\right)$ & $3.49 \times 10^{-}$ & $3.75 \times 10^{-}$ & $3.45 \times 10^{-}$ & $1.43 \times 10^{-3}$ & $3.74 \times 11$ \\
\hline & & $\mathrm{Na}$ & $1.40 \times 10^{-}$ & $1.64 \times 10^{-}$ & $9.15 \times 10^{-}$ & $4.63 \times 10^{-3}$ & $2.01 \times 11$ \\
\hline & & $\mathbf{S i}\left(\mathrm{g} / \mathrm{m}^{2}\right)$ & $4.27 \times 10^{-}$ & $5.16 \times 10^{-}$ & $1.95 \times 10^{-}$ & $3.30 \times 10^{-4}$ & $9.61 \times 11$ \\
\hline & & I $\left(\mathrm{g} / \mathrm{m}^{2}\right)$ & ---* & $3.55 \times 10^{-}$ & $1.76 \times 10^{-}$ & $---*$ & $5.21 \times 11$ \\
\hline
\end{tabular}

* Microwave digestion data is not available for I.

Table 3b. Microwave digestion values from original samples, following coal removal, for various elements present in the FBSR and BSR granular and monolith products.

\begin{tabular}{cccccc}
\hline & $\begin{array}{c}\text { P1-B } \\
\text { granular } \\
\text { as } \\
\text { received }\end{array}$ & $\begin{array}{c}\text { P1-B } \\
\text { granular } \\
\text { roasted }\end{array}$ & $\begin{array}{c}\text { P1-B } \\
\text { monolith }\end{array}$ & $\begin{array}{c}\text { BSR } \\
\text { granular } \\
\text { as } \\
\text { received }\end{array}$ & $\begin{array}{c}\text { BSR B } \\
\text { granular } \\
\text { roasted }\end{array}$ \\
\hline $\mathbf{A l}(\mathrm{ug} / \mathrm{g})$ & $1.71 \times 10^{3}$ & $1.71 \times 10^{3}$ & $2.3 \times 10^{1}$ & $1.16 \times 10^{3}$ & $1.19 \times 10^{3}$ \\
$\mathbf{R e}(\mathrm{ug} / \mathrm{g})$ & $6.9 \times 10^{1}$ & $6.7 \times 10^{1}$ & $2.8 \times 10^{1}$ & $4.10 \times 10^{1}$ & $4.00 \times 10^{1}$ \\
$\mathbf{N a}(\mathrm{ug} / \mathrm{g})$ & $1.18 \times 10^{4}$ & $1.14 \times 10^{4}$ & $4.63 \times 10^{4}$ & $5.82 \times 10^{3}$ & $5.51 \times 10^{3}$ \\
$\mathbf{S i}(\mathrm{ug} / \mathrm{g})$ & $4.57 \times 10^{2}$ & $4.58 \times 10^{2}$ & $1.19 \times 10^{3}$ & $4.06 \times 10^{2}$ & $4.43 \times 10^{2}$ \\
$\mathbf{I}(\mathrm{ug} / \mathrm{g})$ & $2.58 \times 10^{2}$ & $1.07 \times 10^{2}$ & $7.70 \times 10^{1}$ & $1.30 \times 10^{1}$ & $1.30 \times 10^{1}$ \\
\hline
\end{tabular}




\subsection{X-ray Diffraction}

Quantitative XRD analysis was obtained from a variety of FBSR sample types and preparations. The diffractograms are shown in Figure 2 while the distribution of the various phases obtained from these samples are summarized in Table 3. Characteristic peaks corresponding to the major phases are indicated for the low angle peaks; at higher angles the observed peaks are composites from the different phases. Additional peak identification for sample BSR G is shown in the supplemental information.

Table 4. Quantitative XRD results (weight \%) for the FBSR P1B samples used in this study.

\begin{tabular}{|c|c|c|c|c|c|c|c|}
\hline & \multicolumn{2}{|c|}{ BSR } & \multicolumn{5}{|c|}{ Hazen P1B } \\
\hline $\begin{array}{l}\text { Phase } \\
\text { ICSD No. }{ }^{1} \\
\text { Chemical Formula }\end{array}$ & $\mathbf{G}^{2}$ & $\mathbf{M}^{3}$ & G & $\begin{array}{c}\mathrm{G}, \\
\mathrm{EtOH}^{4}\end{array}$ & $\begin{array}{c}\text { G, } \\
\text { EtOH, } \\
\text { no coal }^{5}\end{array}$ & $\mathbf{M}$ & $\begin{array}{c}\text { M, } \\
\text { EtOH }\end{array}$ \\
\hline $\begin{array}{l}\text { Nosean } \\
\text { ICSD } 203102 \\
\mathrm{Na}_{8.08} \mathrm{Al}_{6} \mathrm{Si}_{6} \mathrm{O}_{24}- \\
\left(\mathrm{SO}_{4}\right)_{0.98}\left(\mathrm{H}_{2} \mathrm{O}\right)_{0.96}\end{array}$ & 20.6 & 11.2 & 7.1 & 5.5 & 6.4 & 6.2 & 6.1 \\
\hline $\begin{array}{l}\text { Na-Nepheline } \\
\text { ICSD } 155001 \\
\mathrm{Na}_{4} \mathrm{Al}_{4} \mathrm{Si}_{4} \mathrm{O}_{16}\end{array}$ & 26.7 & 12.6 & 12.0 & 10.5 & 12.0 & 6.0 & 5.4 \\
\hline $\mathrm{NaAlSiO}_{4}$ & 25.1 & 9.6 & 14.4 & 14.5 & 15.5 & 5.1 & 5.1 \\
\hline $\begin{array}{l}\text { Quartz } \\
\text { ICSD } 162490 \\
\alpha-\mathrm{SiO}_{2}\end{array}$ & $--^{6}$ & -- & 0.3 & 2.6 & 1.8 & 1.2 & 1.4 \\
\hline $\begin{array}{l}\text { Thermonatrite } \\
\text { ICSD } 1852 \\
\mathrm{Na}_{2} \mathrm{CO}_{3} \cdot \mathrm{H}_{2} \mathrm{O}\end{array}$ & -- & -- & -- & -- & -- & 1.0 & 2.5 \\
\hline
\end{tabular}




\begin{tabular}{|c|c|c|c|c|c|c|c|}
\hline $\begin{array}{l}\text { Na-Faujasite } \\
\text { ICSD } 87850 \\
\mathrm{Na}_{2.92} \mathrm{Al}_{3} \mathrm{Si}_{3} \mathrm{O}_{12}\end{array}$ & -- & -- & -- & -- & -- & 2.6 & 3.0 \\
\hline $\begin{array}{l}\text { Anatase } \\
\text { ICSD } 63711 \\
\mathrm{TiO}_{2}\end{array}$ & -- & -- & 0.4 & 0.6 & 0.4 & -- & -- \\
\hline $\begin{array}{l}\text { Hematite } \\
\text { ICSD } 15840 \\
\alpha-\mathrm{Fe}_{2} \mathrm{O}_{3}\end{array}$ & -- & -- & -- & 1.7 & 2.0 & -- & -- \\
\hline $\begin{array}{l}\text { Illite } \\
\text { ICSD } 166961 \\
\left(\mathrm{~K}_{0.60} \mathrm{Ca}_{0.03} \mathrm{Na}_{0.01}\right)- \\
\left(\mathrm{Al}_{1.86} \mathrm{Mg}_{0.14}\right)- \\
\left(\mathrm{Si}_{3.27} \mathrm{Al}_{0.73}\right) \mathrm{O}_{10} \\
(\mathrm{OH})_{2}\end{array}$ & -- & -- & -- & 1.1 & 0.8 & -- & -- \\
\hline $\begin{array}{l}\text { Chesnokovite } \\
\text { ICSD } 250422 \\
\mathrm{Na}_{2} \mathrm{SiO}_{2}(\mathrm{OH})_{2} \cdot 8 \mathrm{H}_{2} \mathrm{O}\end{array}$ & -- & 12.6 & -- & -- & -- & -- & -- \\
\hline Amorphous & 27.6 & 54.0 & 65.7 & 63.5 & 61.0 & 78.0 & 76.5 \\
\hline
\end{tabular}

${ }^{1}$ Entry number in the Inorganic Crystal Structure Database (http://www.fiz-karlsruhe.de/icsd.html)

${ }^{2}$ granular, "as-is"

${ }^{3}$ monolith, "as-is"

${ }^{4}$ washed with ethanol

${ }^{5}$ residual coal removed by combustion

${ }^{6}$ none detected

Based on the XRD analyses, a high proportion of amorphous material is indicated. In our analyses "amorphous" material is defined by the balance of material not accounted for in the crystalline materials identified (Table 3). This definition includes any unidentified phases below the detection threshold, compounds with a crystallite size less than $\sim 5 \mathrm{~nm}$, and traditional non-crystalline material, thus giving rise to the broad peak seen at $\sim 30^{\circ} 2 \theta$ in the diffraction patterns. In all cases, the peaks associated with 
the $\sim 10 \mathrm{wt} \%$ internal corundum standard dominate the scan, and support the result showing a very large amorphous content.

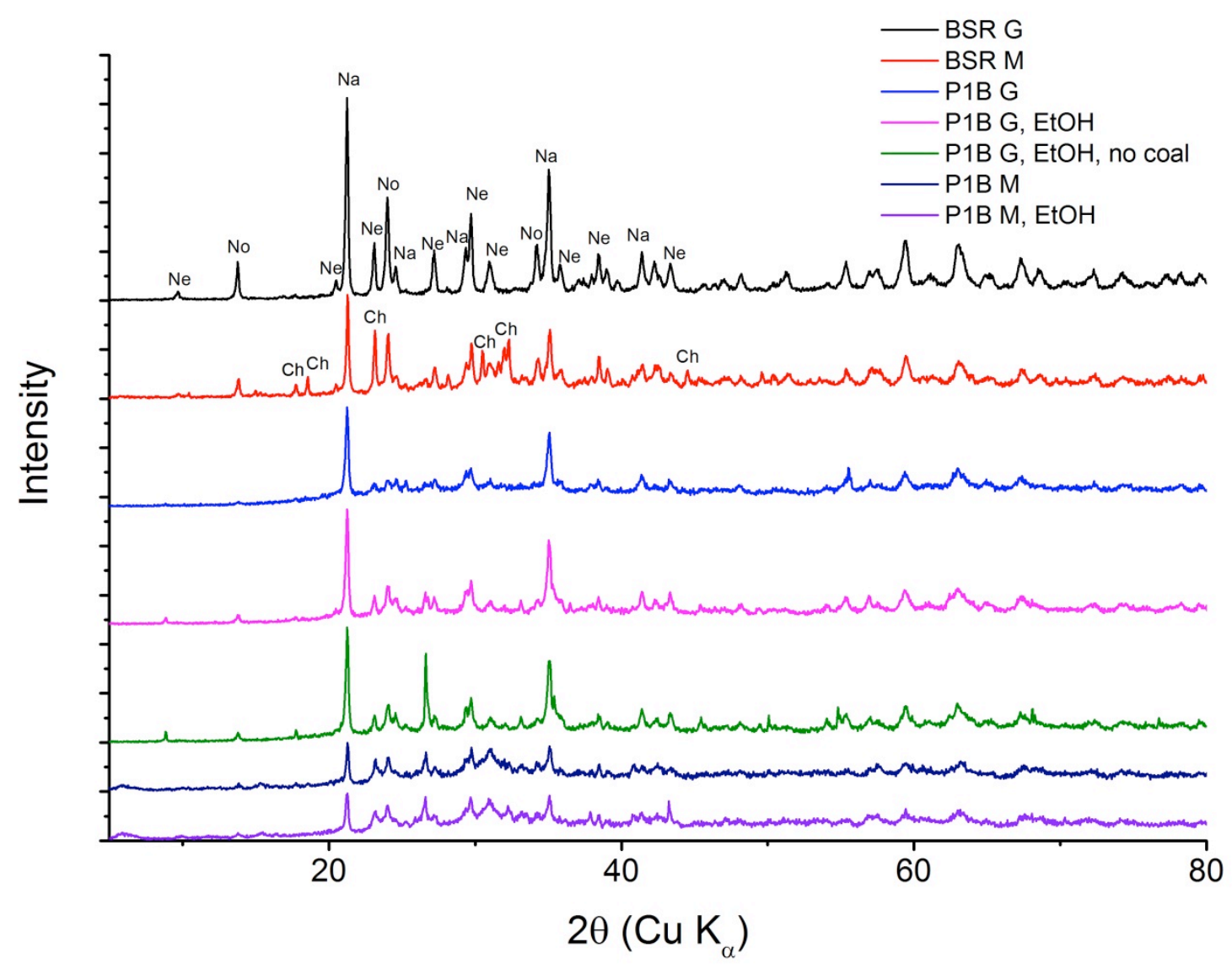

Figure 2. X-ray diffraction of various FBSR sample materials. Low angle peaks characteristic of nepheline $(\mathrm{Ne})$, nosean (No), the new $\mathrm{NaAlSiO}_{4}$ phase $(\mathrm{Na})$, and chesnokovite $(\mathrm{Ch})$ are marked.

A crystalline $\mathrm{NaAlSiO}_{4}$ phase was found in all seven of the FBSR samples with a diffraction pattern matching that reported previously [51]. The crystal structure of this phase has not been reported, but was solved using the diffraction data collected from the FBSR granular "as-is" sample. The Supplementary Material contains more information about this phase and shows detailed figures of the match with the 
database pattern, and of the fit resulting from Rietveld refinement of the structure. Solution of the structure was necessary to carry out the quantitative phase analysis since our method is based on calculating diffraction patterns from crystal structures. The structure of the crystalline $\mathrm{NaALSiO}_{4}$ phase is based on the cristobalite structure with paired $\mathrm{Na}$ and $\mathrm{Al}$ cations substituting for half of the Si cations. This structure is represented in Figure 3. Atomic coordinates are given in Table 4. Si-O and Al-O interatomic distances are 1.66 $\AA$ and 1.55-1.68 $\AA$ respectively, which are consistent with expected bond lengths for these elements. $\mathrm{Na}$ atoms are positioned in cavities in the structure formed from opposing hexagonal rings of $(\mathrm{Si}, \mathrm{Al})-\mathrm{O}$ tetrahedral with $\mathrm{Na}-\mathrm{O}$ distances between 2.55 and $3.70 \AA$. This is reminiscent of the positioning of $\mathrm{Na}$ in sodalite cages connected through hexagonal prisms. Sodalite is a desirable product of the FBSR process due to its potential to sequester various radionuclides and contaminants of concern $[52,53,54,55,56,57$.

Table 4. Crystal structure of $\mathrm{NaAlSiO}_{4}$ phase solved from powder data. Space group $P 3_{1}, a=5.1164(4)$, $c=12.5091(18) \AA$. Isotropic displacement parameter $\mathrm{B}=1.39(11)$ applied to all atoms. $\mathrm{O}$ atoms were refined as rigid bodies based on tetrahedral $\mathrm{SiO}_{4}$ geometry and have ESDs derived from refined $\mathrm{Si}$ positions and $\mathrm{Si}-\mathrm{O}$ bond lengths.

\begin{tabular}{cccc}
\hline Site & $\mathbf{x}$ & $\mathbf{y}$ & $\mathbf{z}$ \\
& & & \\
\hline $\mathrm{Na} 1$ & $0.661(8)$ & $.086(7)$ & $0.163(3)$ \\
$\mathrm{Si} 1$ & $-0.003(7)$ & $0.756(4)$ & 0 \\
$\mathrm{~A} 11$ & $0.342(11)$ & $.400(7)$ & $0.089(4)$ \\
$\mathrm{O} 1$ & $-0.048(9)$ & $0.670(9)$ & $-0.123(9)$ \\
$\mathrm{O} 2$ & $0.666(9)$ & $0.667(9)$ & $0.054(9)$ \\
O3 & $0.231(9)$ & $0.125(9)$ & $0.013(9)$ \\
O4 & $0.139(9)$ & $0.568(9)$ & $0.062(9)$ \\
\hline
\end{tabular}




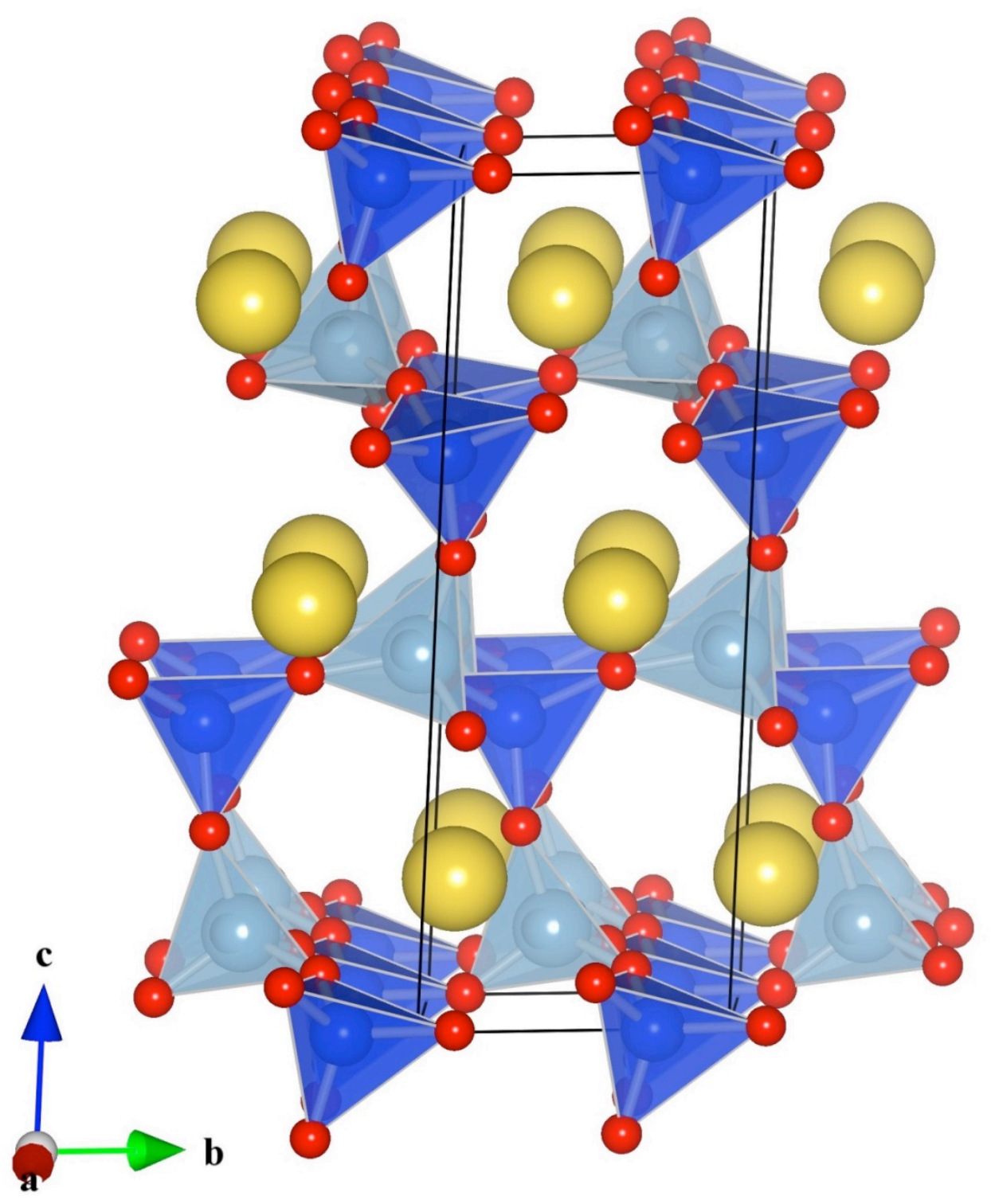

Figure 3. Representation of the crystalline $\mathrm{NaAlSiO}_{4}$ structure, created using VESTA crystallography software, identified in all of the FBSR samples. The diffraction data from this structure were previously reported by Nayak and Kutty [34]. The Na interatomic distance along the a-b axis is $5.12 \AA$. In the above crystal structure the $\mathrm{Na}$ atoms are yellow, $\mathrm{Si}$ atoms are dark blue, $\mathrm{Al}$ atoms are light blue, and $\mathrm{O}$ atoms are red. 


\subsection{Scanning Electron Microscopy/Energy Dispersive X-ray Spectroscopy}

SEM images of P1BG scans revealed discrete blocky, angular grains, on a scale of about $20 \mu \mathrm{m}$, with rough textured surfaces as seen in Figures $4 \mathrm{a}$ and $\mathrm{b}$. Incomplete contact between needle and platy components leaves numerous small void spaces. Figure $4 \mathrm{c}$ shows another P1B sample with a more platelike appearance indicating that the morphology of the sample may vary with each particle. The planar surfaces appear to be cleavage or fracture faces that indicate the crystalline nature of the primary particle otherwise obscured by the plate and needle coating.

Figure 5 shows a polished cross section of a P1BG particle. This large particle is roughly five times larger than those in Figure 4. EDS spectra results from P1BG analyses consistently illustrate the similarity in the occurrence and proportions of $\mathrm{Na}, \mathrm{Al}$, and $\mathrm{Si}$ in these FBSR samples. For all EDS scans we note that the presence of Re, a chemical surrogate for Tc, would not be detected due to the low intensity signal provided by such low concentrations in the original samples (Table $2 b$ ). The inner third, or core, of the particle displays distinctly different image intensity than the outer two thirds. EDS are similar to those of the previously mentioned surface scans but have a higher abundance of metals and other analytes of interest such as $\mathrm{Ti}, \mathrm{Fe}, \mathrm{Pb}, \mathrm{Cr} \mathrm{Ni}, \mathrm{I}$, and $\mathrm{Cl}$. The metals exist as separate phases from the primary NAS mineral, most likely as spinels, created from the iron oxide added to encapsulate these metals [44]. In the SEM/EDS elemental mapping (Figure 6) there is a strong correlation between the

presence of $\mathrm{Na}, \mathrm{Al}$, and $\mathrm{Si}$ while $\mathrm{Fe}$ is generally excluded from these areas. There is evidence of potential correlation between $\mathrm{S}$ and $\mathrm{Ti}$, while Ni may have some correlation with Fe.

SEM/EDS results of BSRG samples, as seen in Figure 7 and Table 5, reveal greater variation in particle size with fewer angular and planar features. BSRG particles generally appeared to be more rounded, amorphous, and with smooth irregular surfaces. Among the different BSRG sites, EDS profiles for O, Na, 

metals such as Ti and Fe.
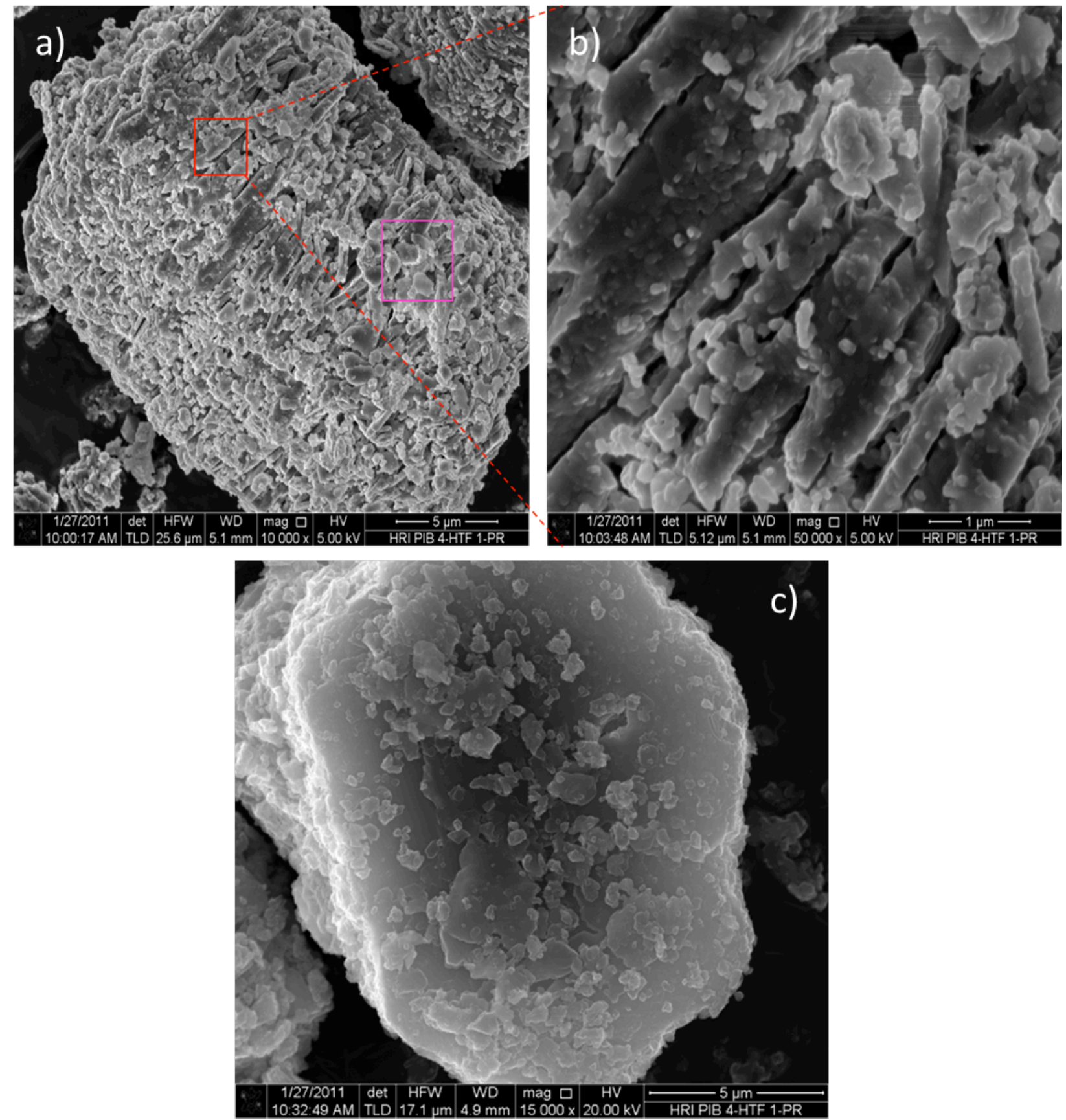

Figure 4. a) SEM micrograph of P1BG sample demonstrating the porosity of the material, b) the same particle at higher magnification, c) another P1BG material showing a more plate-like morphology. 


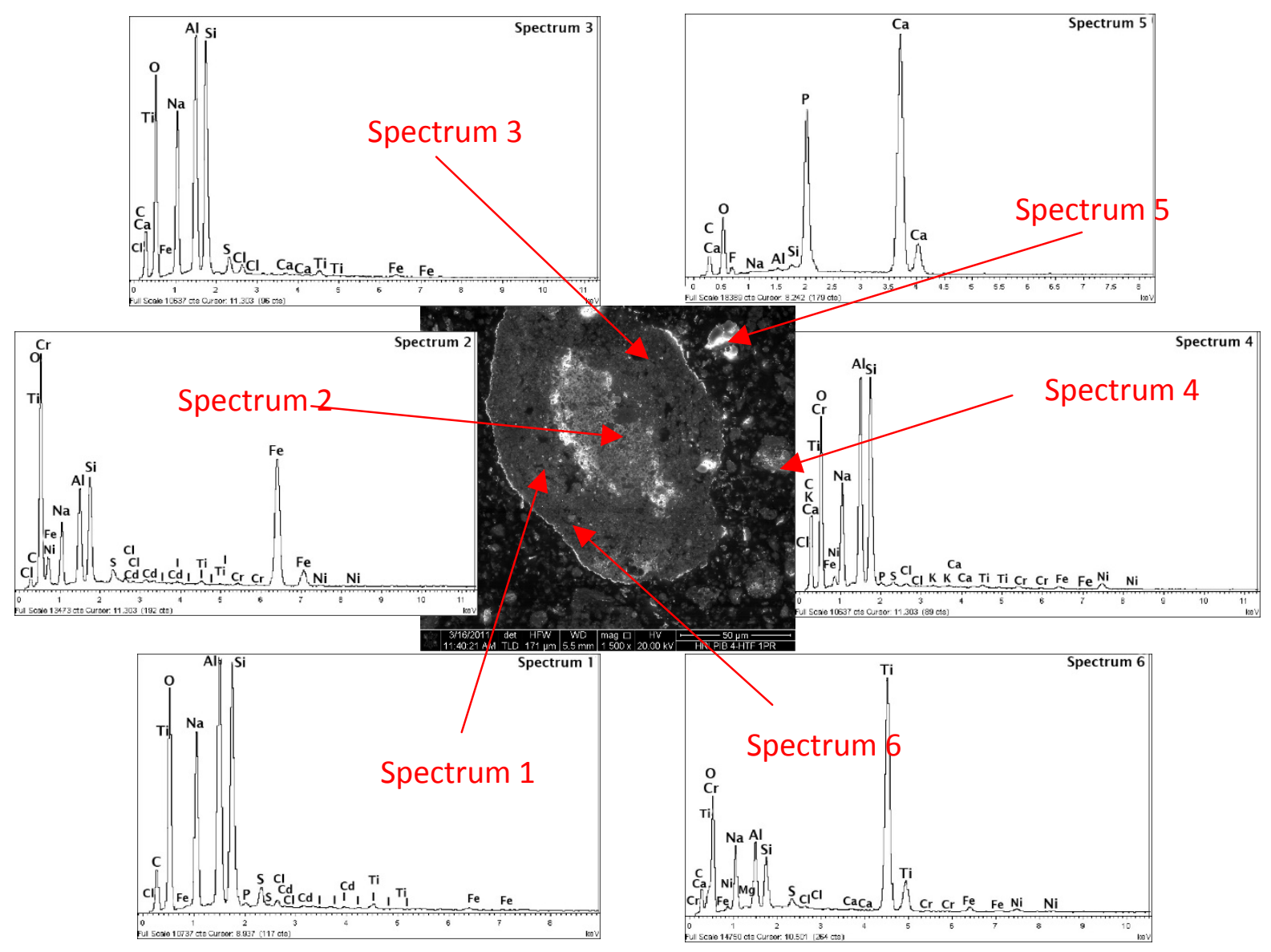

Figure 5. SEM image of P1BG polished cross section and corresponding EDS spectra. 

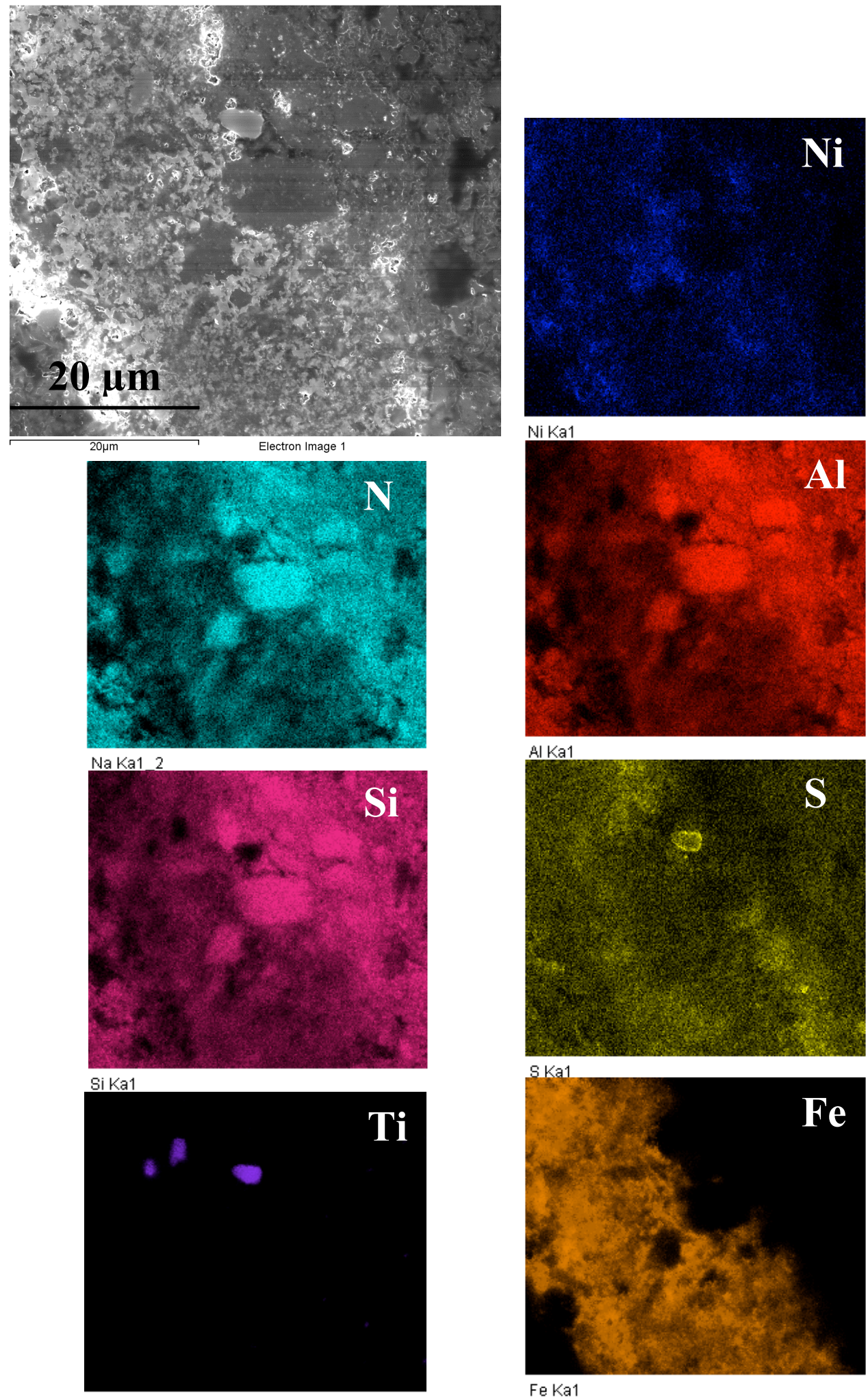

Figure 6. P1B polished cross section SEM elemental mapping. 


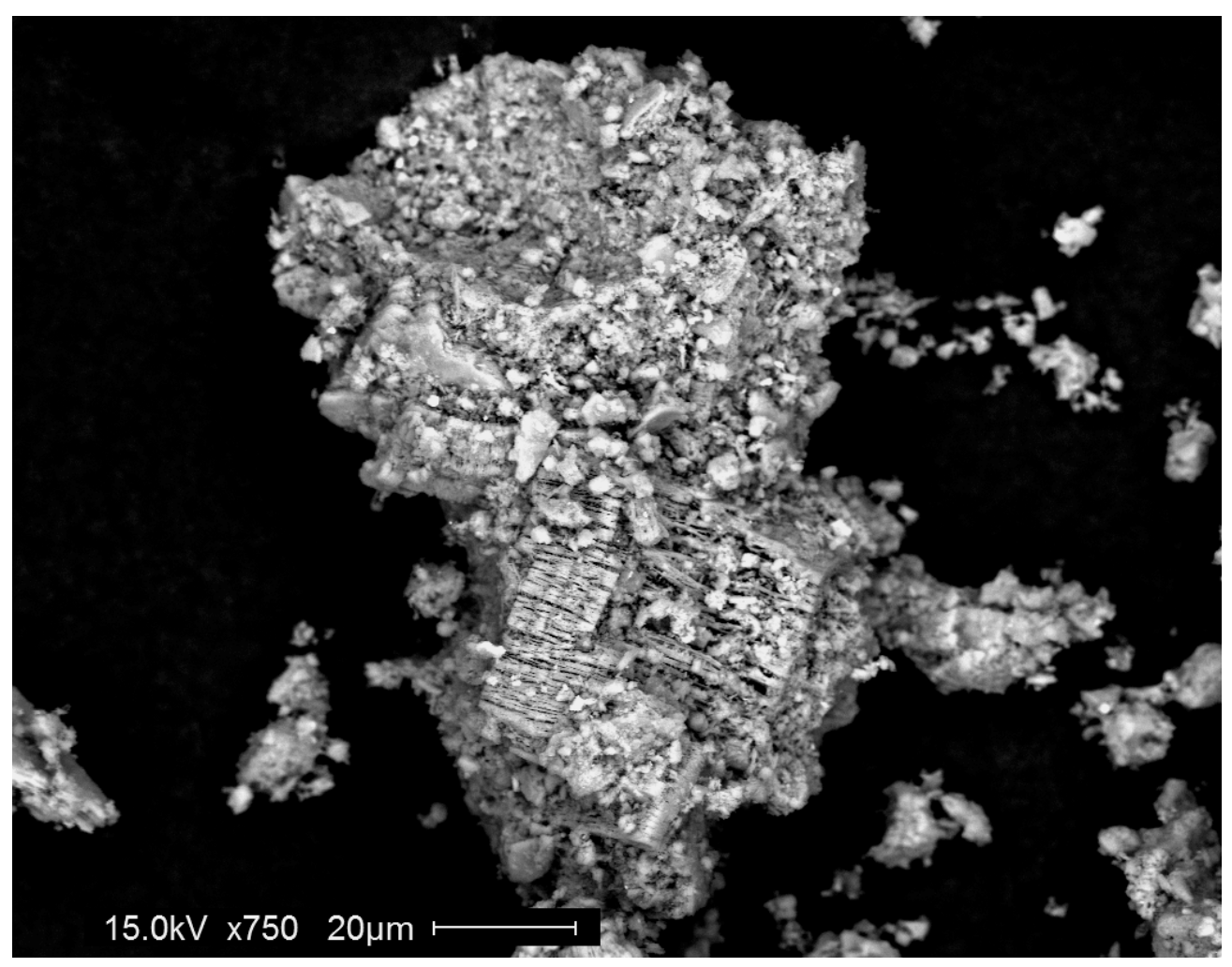

Figure 7. SEM micrograph of BSRG sample.

Table 5. BSRG sample EDS corresponding to SEM micrograph in Figure 6.

\begin{tabular}{lcr}
\hline Element & Wt \% & At \% \\
\hline $\mathrm{O}$ & 43.79 & 55.85 \\
$\mathrm{Na}$ & 17.48 & 15.51 \\
$\mathrm{Al}$ & 19.06 & 14.41 \\
$\mathrm{Si}$ & 19.15 & 13.91 \\
$\mathrm{P}$ & 0.26 & 0.17 \\
$\mathrm{~S}$ & 0.13 & 0.08 \\
$\mathrm{Ti}$ & 0.06 & 0.03 \\
$\mathrm{Fe}$ & 0.08 & 0.03 \\
\hline Total & 100 & 100
\end{tabular}




\subsection{Leaching Tests}

\subsubsection{Product Consistency Test (PCT)}

The normalized release values obtained from these tests, including final solution $\mathrm{pH}$, may be seen in Table 1. The normalized released, NL $\left(\mathrm{g} / \mathrm{m}^{2}\right)$ is given through the following equation:

$N L=\frac{C_{i} / C_{o}}{S / V}$

Where $C_{i}$ is the concentration of element $i$ measured in solution $\left(\mathrm{g} / \mathrm{m}^{3}\right), \mathrm{C}_{0}$ is the concentration of the element in the starting material $\left(\mathrm{g} / \mathrm{m}^{3}\right), \mathrm{S}$ is the surface area of the mineral obtained from BET measurements $\left(\mathrm{m}^{2}\right)$ and $\mathrm{V}$ is the volume of the contacting solution $\left(\mathrm{m}^{3}\right)$.

To be considered an acceptable waste form, a material should demonstrate a higher chemical durability than the Environmental Assessment (EA) glass [normalized mass loss $\left(\mathrm{NL}_{\mathrm{Na}}\right)=6.81 \pm 0.95 \mathrm{~g} / \mathrm{m}^{2}$ ] [48]. In the case of the granular and monolith materials for both the BSR andP1B product, sodium release is near $0.01 \mathrm{~g} / \mathrm{m}^{2}$, thus falling well below this limit. Lower values were found for $\mathrm{Si}, \mathrm{Al}, \mathrm{I}, \mathrm{Cs}$, and Re used as a chemical.surrogate for Tc. A similar trend has been observed in a separate study that reported 7-day PCT values for FBSR product produced at the engineering scale [59]. However, that test shows that the normalized release values are the same or slightly higher than the EA Na release values measured for the EA glass after a one year PCT method experiment.

A critical component in determination of NL values from the PCT is an accurate knowledge of the material surface area available for water contact and subsequent release of elements from the original material. If the geometric surface area, $\mathrm{SA}_{\text {geo }}$, of the tested material is used instead of the BET surface area, $\mathrm{SA}_{\mathrm{BET}}$, then the $\mathrm{NL}$ values increase by two orders of magnitude and are closer to the values measured for the EA glass. The $\mathrm{SA}_{\text {geo }}$ can be estimated using measured values for the average particle size, and material density, assuming that all particles have a spherical morphology [59]. Previously, it has been noted that the true reactive surface area used in release calculations typically lies between $\mathrm{SA}_{\text {geo }}$ and 
$\mathrm{SA}_{\mathrm{BET}}[59,60]$. By using this assumption, the NL values for the results discussed in this manuscript are within an acceptable range even with the uncertainty in the true reactive SA. It should be noted that a similar issue for the surface area of glass, which is considered the best available technology for radioactive waste treatment, is also still under debate [61].

\subsubsection{Toxicity Characteristic Leaching Procedure (TCLP)}

Results from the TCLP test are listed in Table 6 along with the maximum limits for the US Environmental Protection Agency (EPA) TCLP and the Universal Treatment Standards (UTS). The results pass both the TCLP and the (UTS) for listed wastes. A more detailed discussion of these results can be found in Section 4 . 
Table 6. Results from the Toxicity Characteristic Leaching Test (TCLP) for the eight Resource Conservation and Recovery Act (RCRA) metals (40 CFR 261.24) as well as the Universal Treatment Standards (UTS) (40 CFR 268.48).

\begin{tabular}{|c|c|c|c|c|c|c|}
\hline & $\begin{array}{l}\text { TCLP } \\
\text { Limit } \\
(\mathrm{mg} / \mathrm{L})\end{array}$ & $\begin{array}{c}\text { UTS } \\
\text { Limit } \\
(\mathrm{mg} / \mathrm{L})\end{array}$ & $\begin{array}{c}\text { P1BG (Eng } \\
\text { Scale } \\
\text { Granular) } \\
(\mathrm{mg} / \mathrm{L})\end{array}$ & $\begin{array}{c}\text { BSRG } \\
\text { (Bench Scale } \\
\text { Granular) } \\
(\mathrm{mg} / \mathrm{L})\end{array}$ & $\begin{array}{c}\text { P1BM (Eng } \\
\text { Scale } \\
\text { Monolith) } \\
(\mathrm{mg} / \mathrm{L})\end{array}$ & $\begin{array}{c}\text { BSRM } \\
\text { (Bench Scale } \\
\text { Monolith) } \\
(\mathrm{mg} / \mathrm{L})\end{array}$ \\
\hline $\mathrm{Ag}$ & 5 & 0.14 & $<\mathrm{MDL}$ & $6.5 \pm 5.0 \times 10^{-4}$ & $<\mathrm{MDL}$ & $3.5 \pm 0.7 \times 10^{-4}$ \\
\hline As & 5 & 5 & $4.5 \pm 3.5 \times 10^{-2}$ & $<\mathrm{MDL}$ & $2.0 \pm 0.1$ & $2.2 \pm 0.1$ \\
\hline $\mathrm{Ba}$ & 100 & 21 & $2.2 \pm 0.2 \times 10^{-1}$ & $2.5 \pm 0.1 \times 10^{-1}$ & $8.6 \pm 0.7 \times 10^{-3}$ & $1.6 \pm 0.3 \times 10^{-1}$ \\
\hline $\mathrm{Cd}$ & 1 & 0.11 & $3.1 \pm 0.1$ & $<\mathrm{MDL}$ & $1.8 \pm 1.3 \times 10^{-2}$ & $5.5 \pm 0.7 \times 10^{-4}$ \\
\hline $\mathrm{Cr}$ & 5 & 0.6 & $6.3 \pm 2.1 \times 10^{-2}$ & $1.2 \pm 0.1$ & $4.6 \pm 1.5 \times 10^{-2}$ & $6.5 \pm 1.4 \times 10^{-2}$ \\
\hline $\mathrm{Hg}$ & 0.2 & 0.025 & $1.9 \pm 1.0 \times 10^{-5}$ & $<\mathrm{MDL}$ & $<\mathrm{MDL}$ & $5.0 \pm 0.0 \times 10^{-5}$ \\
\hline $\mathrm{Ni}$ & --- & 11 & $1.6 \pm 0.0$ & $2.5 \pm 0.4 \times 10^{-2}$ & $2.8 \pm 0.7 \times 10^{-2}$ & $1.2 \pm 0.2 \times 10^{-3}$ \\
\hline $\mathrm{Pb}$ & 5 & 0.75 & $8.6 \pm 3.1 \times 10^{-2}$ & $2.9 \pm 3.0 \times 10^{-2}$ & $1.5 \pm 0.3 \times 10^{-1}$ & $1.5 \pm 0.6 \times 10^{-1}$ \\
\hline $\mathrm{Sb}$ & --- & 1.15 & $3.2 \pm 0.2 \times 10^{-1}$ & $9.0 \pm 0.0 \times 10^{-3}$ & $1.1 \pm 0.1$ & $1.8 \pm 0.2 \times 10^{-2}$ \\
\hline $\mathrm{Se}$ & 1 & 5.7 & $3.8 \pm 0.6 \times 10^{-1}$ & $1.2 \pm 0.1$ & $1.1 \pm 0.1$ & $4.6 \pm 0.2 \times 10^{-1}$ \\
\hline $\mathrm{Zn}$ & --- & 4.3 & $1.7 \pm 0.2 \times 10^{-1}$ & $3.0 \pm 0.4 \times 10^{-1}$ & $6.9 \pm 6.3 \times 10^{-2}$ & $8.9 \pm 1.3 \times 10^{-2}$ \\
\hline
\end{tabular}

\subsubsection{Single-Pass Flow-Through (SPFT) Test}

Figure 8 shows the results of the measured SPFT effluent $\mathrm{pH}$ for the P1BG and P1BM samples. The dissolution kinetics of the granular P1B sample has been the subject of another publication [48]. When 
comparing effluent $\mathrm{pH}$ values from the $\mathrm{P} 1 \mathrm{BG}$ and $\mathrm{P} 1 \mathrm{BM}$ samples, we note a marked increase in the $\mathrm{pH}$ for the early samples from the monolithic material where the P1BM maximum $\mathrm{pH}$ was 10.5 at a $10 \mathrm{~mL} / \mathrm{d}$ flow rate. In contrast, the maximum $\mathrm{pH}$ observed at the $10 \mathrm{~mL} / \mathrm{d}$ flow rate for the granular P1BG was 9.2, similar to that of the blank sample. Monolith effluent $\mathrm{pH}$ at the other flow rates tested was also higher than that of the granular form. This suggests that the dissolving species from the monolithic materials have a different chemical composition than the granular materials. As shown in the static, 7-day PCT tests, these materials have exhibited end-of-reaction $\mathrm{pH}$ values between 11 and 12. An increase in the $\mathrm{pH}$ of the solution is attributed to the release of $\mathrm{OH}^{-}$from sodium hydroxide that is used as an activator in the production of the geopolymer [62]. Regardless, at longer reaction periods, the effluent $\mathrm{pH}$ decreases to a range that is within the experimental error of the inlet buffer solution. A similar trend is observed when comparing results of the BSRG and BSRM materials.

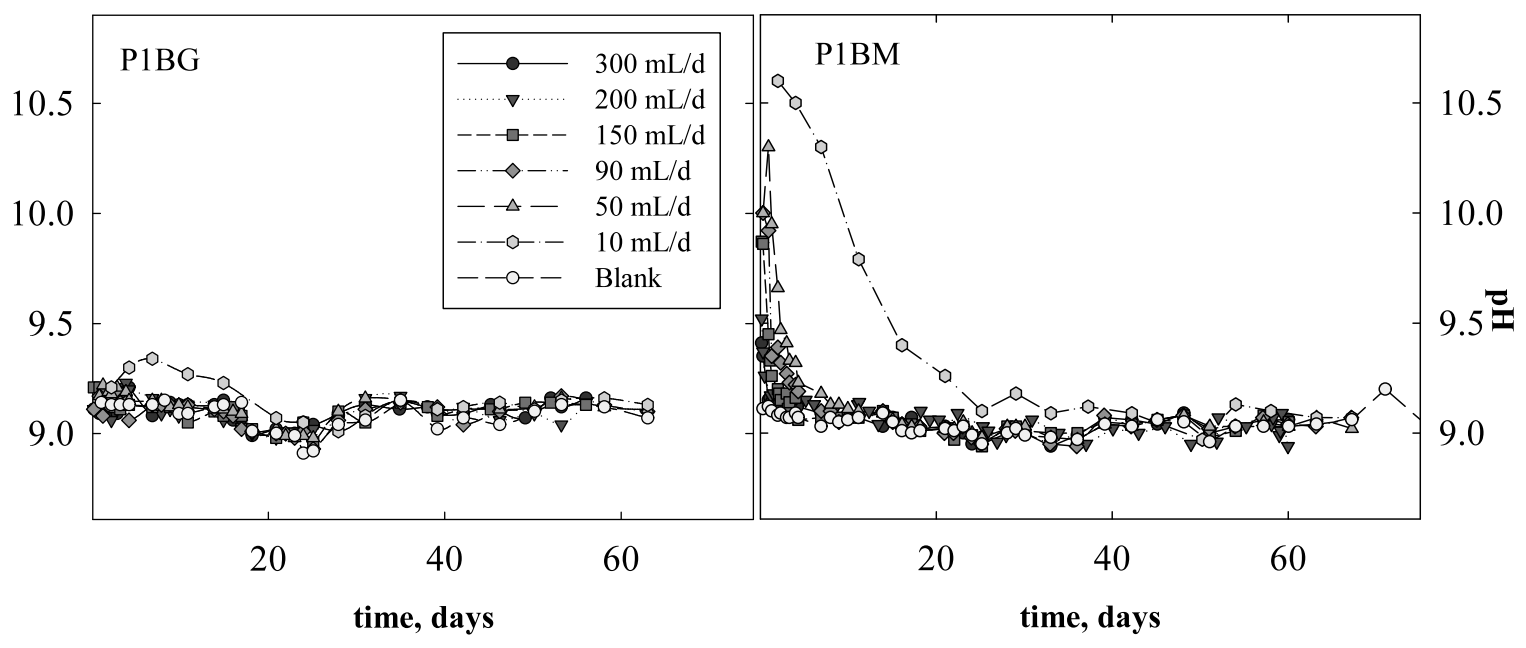

Figure 8. Effluent solution $\mathrm{pH}$ from the four non-radioactive test materials.

For the results given in this section, we focus on the results of the P1B samples because it has been shown that the dissolution kinetics of the P1B and BSR samples behave similarly [48,63]. Figure 9 shows the normalized effluent concentration of $\mathrm{Al}, \mathrm{Si}$, and $\mathrm{Na}$ for $\mathrm{P} 1 \mathrm{BM}$ at 300,150 , and $10 \mathrm{~mL} / \mathrm{d}$. When the concentration of a particular element is constant as a function of time, the system is assumed to have achieved a steady-state condition. In general, steady-state conditions were achieved after about three 
weeks of reaction time. Results indicate that the normalized $\mathrm{Na}$ concentration is greater than $\mathrm{Al}$ and $\mathrm{Si}$ across all the flow rates. The concentration trends for $\mathrm{Na}$ and $\mathrm{Si}$ follow a similar pattern. Though the normalized concentration of $\mathrm{Na}$ is roughly one order of magnitude higher than $\mathrm{Si}$ at very short experimental time periods, once the excess $\mathrm{NaOH}$ is removed the $\mathrm{Na}$ concentrations decrease and converge to a value that is within the experimental error of Si after five days for experiments conducted at 150 and $300 \mathrm{~mL} / \mathrm{d}$ flow rates and 30 days for the $10 \mathrm{~mL} / \mathrm{d}$ flow rate experiment. The normalized $\mathrm{Al}$ concentration is at least two orders of magnitude lower than $\mathrm{Na}$ and $\mathrm{Si}$. The concentration remains low for the first few samplings and then increases to converge with $\mathrm{Na}$ and $\mathrm{Si}$. The increased $\mathrm{Al}$ concentration is directly related to the $\mathrm{pH}$ (Figure 8). During this period of increased $\mathrm{pH}, \mathrm{Al}$ is not released into solution to the same extent as $\mathrm{Na}$ and $\mathrm{Si}$. This trend is not observed with the granular material, P1BG, where $\mathrm{Na}, \mathrm{Al}$, and $\mathrm{Si}$ are released concomitantly due to the absence of a spike in $\mathrm{pH}$ resulting from the excess $\mathrm{NaOH}$ release at short time periods [48]. Similar results were observed when comparing the BSRG and BSRM materials; however the results are not shown here.

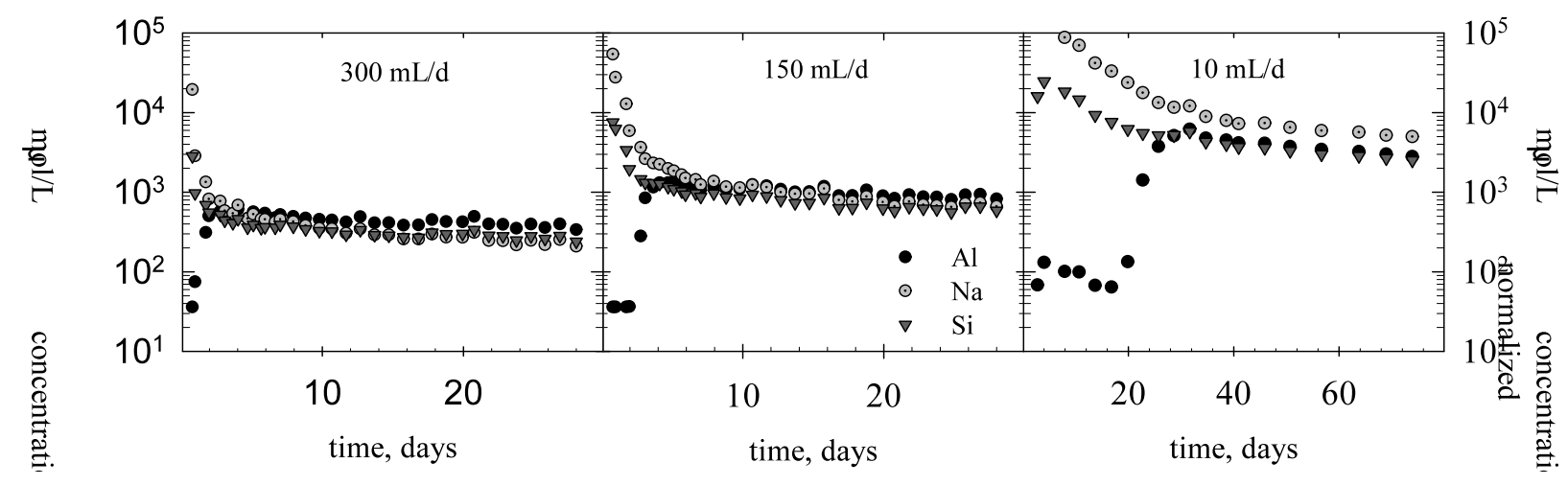

Figure 9. Waste form P1BM SPFT effluent normalized concentration of $\mathrm{Al}, \mathrm{Si}$, and $\mathrm{Na}$ at 300, 150, and $10 \mathrm{~mL} / \mathrm{d}$ at $40{ }^{\circ} \mathrm{C}$ given as a function of time. Note the change in scale for the y-axis of the third graph.

The values are not corrected for background. Error from ICP-OES analysis is $10 \%$.

Figure 10 shows the P1BM release of Cs, I, and Re. Cs, Re, and I are of importance because they either represent radioactive isotopes that are present in LAW or act as a surrogate for a radioactive species of 
concern [64]. Results show that Re and I follow similar trends whereas Cs follows trends more similar to $\mathrm{Na}, \mathrm{Al}$, and $\mathrm{Si}$. This is because cationic species such as $\mathrm{Cs}$ can be substituted for $\mathrm{Na}$ in the feldspathoid mineral [58]. Release of $\operatorname{Re}$ and $\mathrm{I}$ in the monolithic material seems delayed, indicating that the aluminosilicate cage in the sodalite structure has to degrade before these species can be released. The presence of Re in the sodalite cage from the FBSR process has previously been confirmed using X-ray absorption spectroscopy (XAS) $[53,54,55,65]$. Initially high Re and I effluent concentrations decrease and then go through a second maximum with time. The concentration of these elements, at the second maximum, is used to calculate the steady-state dissolution rate because it is similar to the time when a transient steady-state release of $\mathrm{Na}, \mathrm{Al}$, and $\mathrm{Si}$ is observed. Releases of $\mathrm{Cs}, \mathrm{Re}$, and I from the BSRM mineral products show a similar behavior, thus are not given here. The steady-state release rate of the P1BM material based on Si release is $3.4 \pm 1.1 \times 10^{-4} \mathrm{~g} / \mathrm{m}^{2} \mathrm{~d}$ while for the BSRM material the value is 4.4 $\pm 1.6 \times 10^{-4} \mathrm{~g} / \mathrm{m}^{2} \mathrm{~d}$. These results are slightly lower than the values calculated for the B1BG and BSRG materials [48].

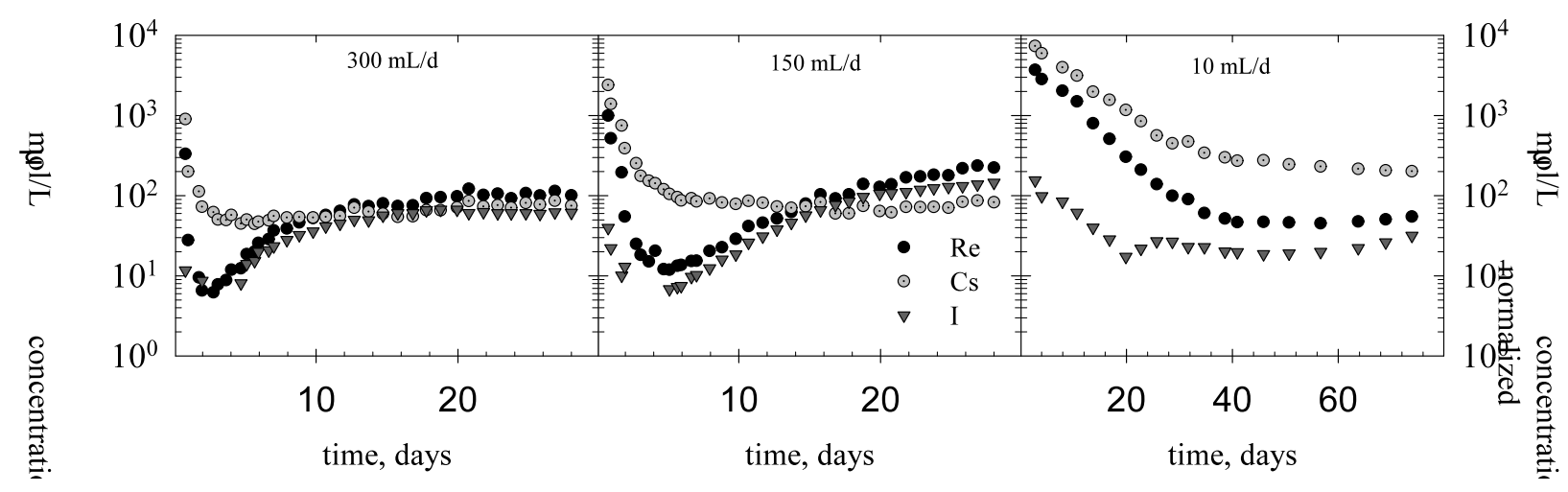

Figure 10. Waste forms P1BM SPFT effluent normalized concentration of Cs, I, and Re at 300, 150, and $10 \mathrm{~mL} / \mathrm{d}$ at $40{ }^{\circ} \mathrm{C}$ given as a function of time. Note the change in scale for the $\mathrm{x}$-axis of the third graph. The values are not corrected for background. Error from ICP-OES analysis is $10 \%$. 


\section{$\underline{4.0 \text { Discussion }}$}

The results in Table 1 indicate that over the 6-month time span the material does not appear to be hygroscopic. Addionally, tests where the product was heated at $525{ }^{\circ} \mathrm{C}$ for two days show that a 2-hour heating duration is adequate for effective coal removal.

Following coal removal, BET surface area analysis was performed. High porosity in the range of 3.3 to $8.1 \mathrm{~m}^{2} / \mathrm{g}$ (Table 2a) is in general agreement the results from other sources $[38,66]$. Overall, the porosity of the material is the most likely explanation for the high measured BET surface area compared to the geometric surface area. It has been noted that an accurate measurement of the surface area is crucial because it is directly related to NL values, which allows for a direct comparison of supplemental waste form performance. At this point, the accurate measurement of the reactive surface area of the FBSR materials remains unresolved (see [59], [60] and [64] for discussion).

XRD indicate up to $65 \mathrm{wt} \%$ of amorphous material in the P1B granular "as received" sample. Taken as a whole, these FBSR samples, formed at relatively low process temperatures $\left(650-800^{\circ} \mathrm{C}\right)$, exhibit a clear predominance of sodium-aluminosilicates existing as separate phases from other metals - particularly iron. Table 3 illustrates the phases identified from XRD of P1B samples. This information, demonstrates the dominant presence of sodium aluminosilicates in the FBSR product material. XRD analysis identified the crystalline NAS phases nosean, nepheline, faujasite, and a new structure related to cristobalite that is represented in Figure 1.

While PCT evaluations are clouded by the uncertainty in surface area, results from the PCT indicate a favorable comparison between the P1B/BSR product and the benchmark standard EA glass. Not only are $\mathrm{Na}$ release rates two orders of magnitude lower than for the EA glass when the geometric surface area is used, but other constituents are even lower than that of Na. Based on these PCT results, the FBSR 
product is more durable than the EA glass. This improved stability might simplify temporary storage requirements between the time of waste form creation and final disposition.

While results from the TCLP show the release of important contaminants fall below the required final solution concentrations, Cd fails the TCLP test. However, the concentration of this element was greatly increased in the engineering scale test to ensure that measurable quantities of the element could be obtained in the leach tests. This increase was required in order to accurately monitor Cd releases from the waste form. Therefore, this element may comply with test limits at more realistic starting concentrations. When the P1B material is in the monolithic form, the solution concentrations for all contaminants decreased by a factor of 100 . A marked performance gain can be realized by converting granular materials to the monolithic form with a geopolymer binder.

SPFT pH studies indicate chemical differences between the monolith and granular product. These differences decrease over time and are thought to be a function of rapid initial dissolution of unreacted $\mathrm{NaOH}$ from the monoliths. Correlated to the high $\mathrm{pH}$ of monolith early-stage leaching samples, is the relatively low concentration of $\mathrm{Al}$ and $\mathrm{I}$. Cs release appears to follow that of $\mathrm{Na}$ and $\mathrm{Si}$, and may be accounted for by the tendency of $\mathrm{Cs}$ to substitute for $\mathrm{Na}$ in feldspathoid structures. Because $\mathrm{Na}$ and $\mathrm{Si}$ are key components of these structures, their dissolution will also influence Cs release. In contrast to other key elements of interest, Re experiences rapid early release, diminishing to levels comparable to that of I. Subsequently, Re and I seemed to be released at similar rates. This may indicate that Re is present in two phases or may experience co-precipitation after initial release at low flow rates such as $10 \mathrm{~mL} / \mathrm{day}$. Results from the PCT and SPFT tests must be combined with other tests, such as Pressurized Unsaturated Flow (PUF) $[65,59,66]$ in order to fully characterize the durability of this material in a long-term subsurface repository.

\section{$\underline{5.0 \text { Conclusion }}$}


Solid-state analyses of the P1B and BSR samples confirm the dominant NAS composition targeted as a sequestering waste form for low activity wastes and clarify phase relations in these multiphase waste forms. The BET surface area was similar for both granular products fabricated at the engineering and bench scale. However, the BET surface areas were higher for both the P1B and BSR monoliths fabricated to encapsulate the granular product because of increased porosity created from the geopolymer. The two methods of sample preparation show similar NL values from PCT tests, pass the TCLP, and have the same crystalline phases. However, the P1B and BSR granular material exhibit a slightly different morphology from SEM imaging. XRD analyses have also demonstrated that the granular material has a higher percent of crystalline phases when compared with the monoliths. This may be due to the large amount of amorphous fly ash used to produce the monolith. The FBSR product successfully transforms waste to sodium aluminosilicate minerals that aid in contaminant capture through incorporation into the crystal structure. The dissolution kinetics calculated from SPFT tests further demonstrate the durability imparted through geopolymer encapsulation of the granular material into a monolith.

\section{$\underline{\text { Role of the Funding Source }}$}

These studies were supported by the U.S. Department of Energy (DOE) through the Office of Environmental Management. Pacific Northwest National Laboratory is operated for the DOE by Battelle Memorial Institute under Contract DE-AC06-76RLO 1830. The funding source had no involvement the collection, analysis, interpretation of data, writing or the decision to submit the article for publication.

\section{Acknowledgements}

The authors would like to thank the management and the entire research team whose hard work and diligence contributed to the production of the data on which this article is based, including: Elsa Cordova, John Stephenson, Sara Strandquist, Denomy Dage, Cristian Iovin, Mike Lindberg, Dennese Smith, Mike Schweiger, Jesse Lang, Charlie Bonham, Mark Sweeney, and Isaac Carroll. The authors would also like to express their appreciation for the efforts of Carol Jansen and her colleagues at Savannah River National 
Laboratory. The research described in this paper was performed in part in the Environmental Molecular Sciences Laboratory, a national scientific user facility sponsored by the U.S. Department of Energy's Office of Biological and Environmental Research and located at Pacific Northwest National Laboratory in Richland, WA.

\section{$\underline{\text { References }}$}

[1] S. Gin, A. Abdelouas, L.J. Criscenti, W.L. Ebert, K. Ferrand, T. Geisler, M.T. Harrison, Y. Inagaki, S. Mitsui, K.T. Mueller, J.C. Marra, CG. Pantano, E.M. Pierce, J.V. Ryan, J. Schofield, C.I. Steefel and J.D. Vienna, "An international initiative on long-term behavior of high-level nuclear waste glass," Materials Today, vol. 16, no. 6, pp. 243-248, June 2013.

[2] United States Environmental Protection Agency (EPA), "Identification and Listing of Hazardous Waste, The Code of Federal Regulations, Title 40, Chapter 1, Part 261," Washington, D.C., 1999.

[3] N. Qafoku, J. H. Westsik Jr., D. M. Strachan, M. M. Valenta, and R. P. Pires, "Secondary Waste Form Down-Selection Data Package-Fluidized Bed Steam Reforming Waste Form. PNNL20704, Pacific Northwest National Laboratory, Richland, WA.

[4] J. D. Vienna, J. V. Ryan, S. Gin and Y. Inagaki, "Current Understanding and Remaining Challenges in Modeling Long-Term Degradation of Borosilicate Nuclear Waste Glasses," International Journal of Applied Glass Science, vol. 4, no. 4, pp. 283-294, 2013.

[5] J. V. Crum, L. Turo, B. Riley, M. Tang and A. Kossoy, "Multi-Phase Glass-Ceramics as a Waste Form for Combined Fission Products: Alkalis, Alkaline Earths, Lanthanides, and Transition Metals," Journal of American Ceramic Society, vol. 95, no. 4, pp. 1297-1303, 2012.

[6] J. J. Neeway, N. P. Qafoku, J. H. Westsik Jr., C. F. Brown, C. Jantzen, and E. M. Pierce, "Radionuclide and contaminant immobilization in the fluidized bed steam reforming waste products.”, Chapter 11 in Radioactive Waste, R. A. Rahmnan, Ed., InTech Europe, Rijeka, Croatia (Local Name: Hrvatska), 2012, pp. 239-262.

[7] G. R. Lumpkin, "Ceramic waste forms for actinides.," Elements, vol. 2, pp. 365-372, 2006.

[8] S. Stefanovsky, S. Yudintsev, R. Giere and G. Lumpkin, "Nuclear waste forms," in Energy, Waste, and the Environment: A Geochemical Perspective., R. P. S. Giere, Ed., Geological Society of London Special Publication, 2004, pp. 36-63. 
[9] J. J. Neeway, N. P. Qafoku, B. D. Williams, K. A. Rod, M. E. Bowden, C. F. Brown, and E. M. Pierce, "Performance of the Fluidized Bed Steam Reforming Product Under Hydraulically Unsaturated Conditions." Journal of Environmental Radioactivity, vol. 131, pp. 119-128, 2013.

[10] J. J. Neeway, N. P. Qafoku, C.F. Brown, and R. A. Peterson, "Characterization and Leaching Tests of the Fluidized Bed Steam Reforming (FBSR) Waste Form for LAW Immobilization.", Proceedings of the Annual Waste Management Symposium (WM2013): International Collaboration and Continuous Improvement, February 24-28, 2013, Phoenix, Arizona, vol.3 pp. 2268-2275, Paper No. 13400, WM Symposia, Tucson, AZ.

[11] A.E. Ringwood, S.E. Kesson, N.G. Ware, W. Hibberson, and A. Major, "Immobilization of high level nuclear reactor wastes in SYNROC," Nature, no. 278, pp. 219-223, 1979.

[12] A.B. Harker, "Tailored ceramics.," in Radioactive Waste Forms for the Future, W. R. E. Lutze, Ed., Amsterdam, North-Holland, 1988, pp. 335-392.

[13] W.J. Weber and J.W. Wald, "Effects of Self-Radiation Damage in Cm-Doped Gd2Ti2O7 and CaZrTi2O7," Journal of Nuclear Materials, no. 138, pp. 196-208, 1986.

[14] J. P. Icenhower, D. M. Strachan, B. P. McGrail, R. D. Sheele, E. A. Rodriguez, J. L. Steele and V. L. Legore, "Dissolution kinetics of pyrochlore ceramics for the disposition of plutonium," Am. Mineral, no. 91, pp. 39-53, 2006.

[15] F.W. Clinard Jr, D.E. Peterson, D.L. Rohr and L.W. Hobbs, "Self-irradiation effects in Pu-238 substituted zironolite I. Temperature dependence damage," Journal of Nuclear Materials, no. 126, pp. 245-254, 1984.

[16] F.W. Clinard Jr, D.L. Rohr and R.B. Roof, "Structural damage in a self-irradiated zirconolitebased ceramic," Nuclear Instruments and Methods in Physics Research B1, pp. 581-586, 1984.

[17] T. O'Holleran and e. al., "Glass-ceramic waste forms for immobilizing plutonium.," in Scientific Basis for Nuclear Waste Management XX., W. T. I. Gray, Ed., Material Research Society, 1997, pp. 1251-1258.

[18] W. Lutze and R.L. Ewing, Eds., Radioactive-waste forms for the future, Amsterdam: NorthHolland Publishing, 1988.

[19] W. Lee, M. Ojovan, M. Stennett and N. Hyatt, "Immobilization of radioactive waste in glasses, glass composite materials, and ceramics.," Adv. Appl. Ceram., vol. 105, no. 1, pp. 3-12, 2006.

[20] D. Caurant, P. Loiseau, O. Majerus, V. Aubin-Chevaldonnet, I. Bardez and A. Quintas, Glasses, Glass-Ceramics, and Ceramics for Immobilization of Highly Radioactive Nuclear Waste., New York: Nova Science Publishers Inc., 2009. 
[21] U. S. N. R. C. (NRC), "Waste Forms Technology and Performance Final Report," The National Acadamies Press, Washington, DC., 2011.

[22] H. Xu, W. Gong, L. Syltebo, W. Lutz, I.L. Pegg, "Duralith geopolymer waste form for Hanford secondary waste: Correlating setting behavior to hydration heat evolution.," Journal of Hazardous Materials, vol. 278, pp. 34-39, 2014.

[23] Q. Li, Z. Sun, D. Tao, Y. Xu, P. Li, H. Cui, J. Zhal, "Immobilization of simulated radionuclide $133 \mathrm{Cs}^{+}$by fly ash-based geopolymer.," Journal of Hazardous Materials, vol. 262, pp. 325-331, 2013.

[24] C. Shi, A. Fernández-Jiménez, "Stabilization/solidification of hazardoius and radioactive wastes with alkali-activated cements.," Journal of Hazardous Materials, vol. 137, pp. 1656-1663, 2006.

[25] E. R. Vance and D. S. Perera, "Geopolymers for Nuclear Waste Immobilisation”, Chapter 18 in Geopolymers - Structure, Processing, Properties, and Industrial Applications” J. L. Provis and J. S. J. van Deventer,. Eds., Woodhead Publishing, 2009, pp. 401-420.

[26] K. Komnitsas, D. Zaharaki, "Geopolymerisation: A review and prospects for the minerals industry.," Minerals Engineering, vol. 20, issue 14, pp. 1261-1277, 2007.

[27] P. Duxson, A. Fernández-Jiménez, J.L. Provis, "Geopolymer technology: the current state of the art.,” Journal of Materials Science, vol. 42, issue 9, pp. 2917-2933, 2007.

[28] J. Temuujin, A. van Riessen, R. Williams, "Influence of calcium compounds on the mechanical properties of fly ash geopolymer pastes.," Journal of Hazardous Materials, vol. 167, issue 1-3, pp. 82-88, 2009.

[29] J.S.J. van Deventer, J.L. Provis, P. Duxson, "Technical and commercial progress in the adoption of geopolymer cement.," Minerals Engineering, vol. 29, special issue, pp. 89-104, 2012.

[30] J.L. Provis, G.C. Lukey and J.S.J. van Deventer, "Do geopolymers actually contain nanocrystalline zeolites? - a reexamination of existing results.," Chemistry of Materials, vol. 17, no. 12, pp. 3075-3085, 2005.

[31] P. Duxson, J.L. Provis, G.C. Lukey, S.W. Mallicoat, W.M. Kriven and J.S.J. van Deventer, "Understanding the relationship between geopolymer composition, microstructure and mechanical properties.," Colloids and Surfaces A: Physicochem. Eng. Aspects, vol. 269, pp. 47$58,2005$.

[32] P. Duxson, S.W. Mallicoat, G.C. Lukey, W.M. Kriven and J.S.J. van Deventer, "The effect of alkali and $\mathrm{Si} / \mathrm{Al}$ ratio on the development of mechanical properties of metakaolin-based geopolymners," Colloids and Surfaces A: Physicochem. Eng. Aspects, no. 292, pp. 8-20, 2007. 
[33] W.K.W. Lee and J.S.J. van Deventer, "The effect of ionic contaminants on the early-age properties of alkali-activated fly ash-based cements," Cement and Concrete Research, no. 32, pp. 577-584, 2002.

[34] J.G.S. van Jaarsveld and J.S,J. van Deventer, "The effect of metal contaminants on the formation and properties of waste-based geopolymers," Cement and Concrete Research, no. 29, pp. 11891200, 1999.

[35] P. Duxson, A. Fernandez-Jimenez, J.L. Provis, G.C. Lukey, A. Palomo and J.S.J. van Deventer, "Geopolymer technology: the current stat of the art," Journal of Material Science, no. 42, pp. 2917-2933, 2007.

[36] C. M. Jantzen, "Engineering Study of the Hanford Low Activity Waste (LAW) Steam Reforming Process (U)," Westinghouse Savannah River Company, Aiken, SC, 2002.

[37] A.L. Olson, N.R. Soelberg, D.W. Marshall and G.L. Anderson, "Fluidized Bed Steam Reforming of Hanford LAW Using THOR Mineralizing Technology, INEEL/EXT-04-02492," Idaho National Engineering and Environmental Laboratory, Idaho Falls, ID, 2004.

[38] N.R. Soelberg, D.W. Marshall, S.O. Bates and D.D. Taylor, "Phase 2 THOR Steam Reforming Tests for Sodium-Bearing Waste Treatment, INEEL/EXT-04-01493," Idaho National Engineering and Environmental Laboratory, Idaho Falls, 2004.

[39] A. Olson, "Report for Treating Hanford LAW and WTP SW Simulants: Pilot Plant Mineralizing Flowsheet, RT-21-002," THOR Treatment Technologies, LLC., Denver, CO, 2009.

[40] S.D. Rassat, L.A. Mahoney, R.L. Russell, S.A. Bryan and R.L. Sell, "Cold Dissolved Saltcake Waste Simulant Development, Preparation, and Analysis, PNNL-14194, Rev.1," Pacific Northwest National Laboratory, Richland, Washington, 2003.

[41] J. M. Pareizs, C.M. Jantzen, and T.H. Lorier, "Durability Testing of Fluidized Bed Steam Reformer (FBSR) Waste Forms for High Sodium Wastes at Hanford and Idaho (U)," Savannah River National Laboratory, Aiken, SC, 2005.

[42] C.M. Jantzen, "Fluidized Bed Steam Reformer (FBSR) Product: Monolith Formation and Characterization, WSRC-STI-2006-00033, Rev. 1," Savannah River National Laboratory, Aiken, SC, 2006.

[43] C. L. Crawford, P.R. Burket, A.D. Cozzi, W.E. Daniel, C.M. Jantzen, and D.M. Missimer, "Evaluation of THOR TM Mineralized Waste Forms (Granular and Monolith) for the DOE Advanced Remediation Technologies (ART) Phase 2 Project. SRNL-STI-2009-00505," Savannah River National Laboratory, Aiken, SC, 2011. 
[44] C.M. Jantzen, E.M. Pierce, C.J. Bannochie, P.R. Burket, A.D. Cozzi, C.L. Crawford, W.E. Daniel, K.M. Fox, C.C. Herman, D.H. Miller, D.M. Missimer, C.A. Nash, M.F. Williams, C.F. Brown, N.P. Qafoku, J.J. Neeway, M.M. Valenta, G.A. Gill, D.J. Swanberf, R.A. Robbins, and L.E. Thompson, "Fluidized Bed Steam Reformed Mineral Waste Form Performance Testing to Support Hanford Supplemental Low Activity Waste Immobilization Technology Selection. SRNL-STI-2011-00387 (in press)," Savannah River National Laboratory, Aiken, S.C., 2015.

[45] ASTM, "ASTM C 1285-02, Standard Test Method for Determining the Chemical Durability of Nuclear Waste Glasses: The Product Consistency Test (PCT)," ASTM International, West Conshohocken, PA, 2008.

[46] United States Environmental Proteciton Agency, "Toxicity Characteristic Leaching Procedure, Method 1311," United States Environmental Protection Agency, 1992.

[47] ASTM, "Standard Practice for Measurement of the Glass Dissolution Rate Using the Single-Pass Flow-Throug Test Method. ASTM C1662-10," ASTM International, West Conshohocken, PA, USA, 2010.

[48] J. J. Neeway, N. P. Qafoku, B. D. Williams, M. M. Snyder, E. M. Pierce and C. F. Brown, "Evidence of Technetium and Iodine Release from a Sodalite-Bearing Ceramic Waste Form," Applied Geochemistry - accepted, 2015.

[49] D.L. Bish and S.A. Howard, "Quantitative Phase Analysis Using the Rietveld Method," J. Appl. Cryst., vol. 21, pp. 86-91, 1988.

[50] R.W. Coelho and A. Cheary, "A Fundamental Parameters Approach to X-ray Line-profile Fitting," J. Appl. Crystallogr, vol. 25, no. 2, pp. 109-121, 1992.

[51] M. Nayak and T.R.N. Kutty, "Luminescence of Fe3+ doped NaAlSiO4 prepared by gel to cryallite conversion," Materials Chemistry and Physics, 1998.

[52] C.M. Jantzen, "Mineralization of Radioactive Wastes by Fluidized Bed Steam Reforming (FBSR): Comparisons to Vitreous Waste Forms, and Pertinent Durability Testing," Savannah River National Laboratory, Aiken, SC, 2008.

[53] J. O. Dickson, J. B. Harsh, M. Flury, and E. M. Pierce, "Immobilizaiton and exchange of perrhenate in sodalite and cancrinite", Microporous and Mesoporous Materials, vol. 214, pp. 115-120, 2015.

[54] J. O. Dickson, J. B. Harsh, M. Flury, W. W. Lukens, and E. M. Pierce, "Competitive Incorporation of Perrhenate and Nitrate in Sodalite", Environmental Science and Technology, vol. 48, pp. 12851-12857, 2014. 
[55] J. O. Dickson, J. B. Harsh, W. W. Lukens, and E. M. Pierce, "Perrhenate incorporation into binary mixed sodalites: The role of anion size and implications for technetium-99 sequestration", Chemical Geology, vol. 395, pp. 138-143, 2015.

[56] N. P. Qafoku, C. C. Ainsworth, J. E. Szecsody, D. L. Bish, J. S. Young, D. E. McCready, and O. S. Qafoku, "Aluminum effect on dissolution and precipitation under hyperalkaline conditions: II. Solid phase transformations", Journal of Environmental Quality, vol. 32, 2364-2372, 2003.

[57] N. Rivera, S. Choi, C. Strepka, K. Mueller, N. Perdrial, J. Chorover, and P. A. O’Day, “Cesium and strontium incorporation into zeolite-type phases during homogeneous nucleation from caustic solutions", American Mineralogist, vol. 96, pp. 1809-1820, 2011

[58] C. Jantzen, N.E. Bibler, D.C. Beam, C. Crawford and M. A. Pickett, "Characterization of the Defense Waste Processing Facility (DWPF) Environmental Assessment (EA) Glass Standard Reference Material (U). WSRC-TR-92-346," Savannah River Site, Aiken, SC, 1993.

[59] E.M. Pierce, "Accelerated Weathering of Fluidized Bed Steam Reformation Material Under Hydraulically Unsaturated Conditions.," Materials Science and Technology, Detroit, 2007.

[60] B.P. McGrail, H.T. Schaef, P.F. Martin, D.H. Bacon, E.A. Rodriguez, D.E. McCready, A.N. Primak and R.D. Orr, "Initial Suitability Evaluation of Steam-Reformed Low Activity Waste for Direct Land Disposal, PNWD-3288," Battelle, Pacific Northwest Division, Richland, 2003.

[61] J.P. Icenhower, C.I. Steefel, (2013) "Experimentally determined dissolution kinetics of SON68 glass at $90 \mathrm{C}$ over a silica saturation interval: Evidence against a linear rate law.," Journal of Nuclear Materials, vol. 439, pp. 137-147, 2013.

[62] E.M. Pierce, R.J. Serne, W. Um, S.V. Mattigod, J.P. Icenhower, N.P. Qafoku, J.H. Westsik Jr. and R.D. Scheele, "Review of Potential Candidate Stabilization Technologies for Liquid and Solid Secondary Waste Streams, PNNL-19122," Pacific Northwest National Laboratory, Richland, WA, 2010.

[63] J. J. Neeway, N. P. Qafoku, B. D. Williams, M. M. Valenta, E. A. Cordova, S. C. Strandquist, D. C. Dage and C. F. Brown, "Single Pass Flow-Through (SPFT) Test Results of Fluidized Bed Steam Reforming (FBSR) Waste Forms used for LAW Immobilization-\#12252," in Waste Management Conference, Phoenix, AZ, 2012.

[64] S.V. Mattigod, P. McGrail, D.E. McCready, L.Q. Wang, K.E. Parker and J.S. Young, "Synthesis and structure of perrhenate sodalite.," Microporous and Mesoporous Materials, vol. 91, pp. 139$144,2006$.

[65] E.M. Pierce, W.W. Lukens, J.P. Fitts, C.M. Jantzen and G. Tang, "Experimental determination of the speciation, partitioning, and release of perrhenate as a chemical surrogate for pertechnetate from a sodalite-bearing multiphase ceramic waste form.," Applied Geochemistry, vol. 42, pp. 47- 
$59,2014$.

[66] T.H. Lorier, J.M. Pareizs and C.M. Jantzen, "Single-Pass Flow Through (SPFT) Testing of Fluidized-Bed Steam Reforming (FBSR) Waste Forms," Savannah River National Laboratory, Aiken, SC, 2005.

\section{Supplementary Material: Identification and structure refinement of the new $\mathrm{NaAlSiO}_{4}$ phase}

X-ray diffraction analysis of all the samples examined in this study showed the presence of peaks corresponding to a phase with the formula $\mathrm{NaAlSiO}_{4}$ in the ICDD database (pattern 00-52-1342). This compound was reported by Nayak and Kutty (reference 45 in the manuscript) from a sol-gel synthesis. The peaks of this phase match well with our experimental patterns and were strongest for the FBSR granular as-is specimen, shown in figure S1 below. 


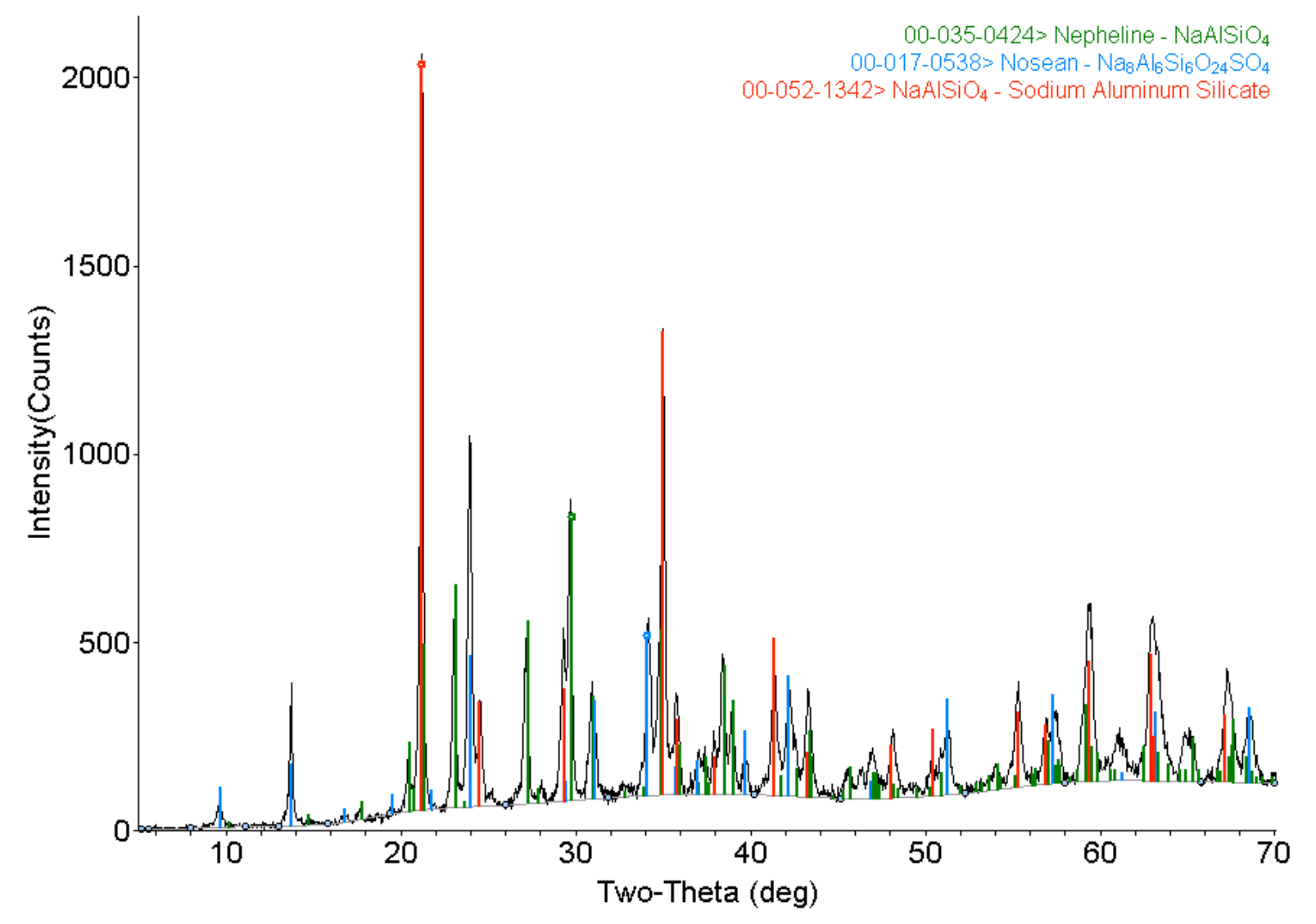

Figure S1. XRD pattern of FBSR "as-is" sample, with peaks from identified phases overlaid as colored vertical bars. NaAlSiO4 (red, 00-52-1342) gave the best agreement from an automated search-match. 


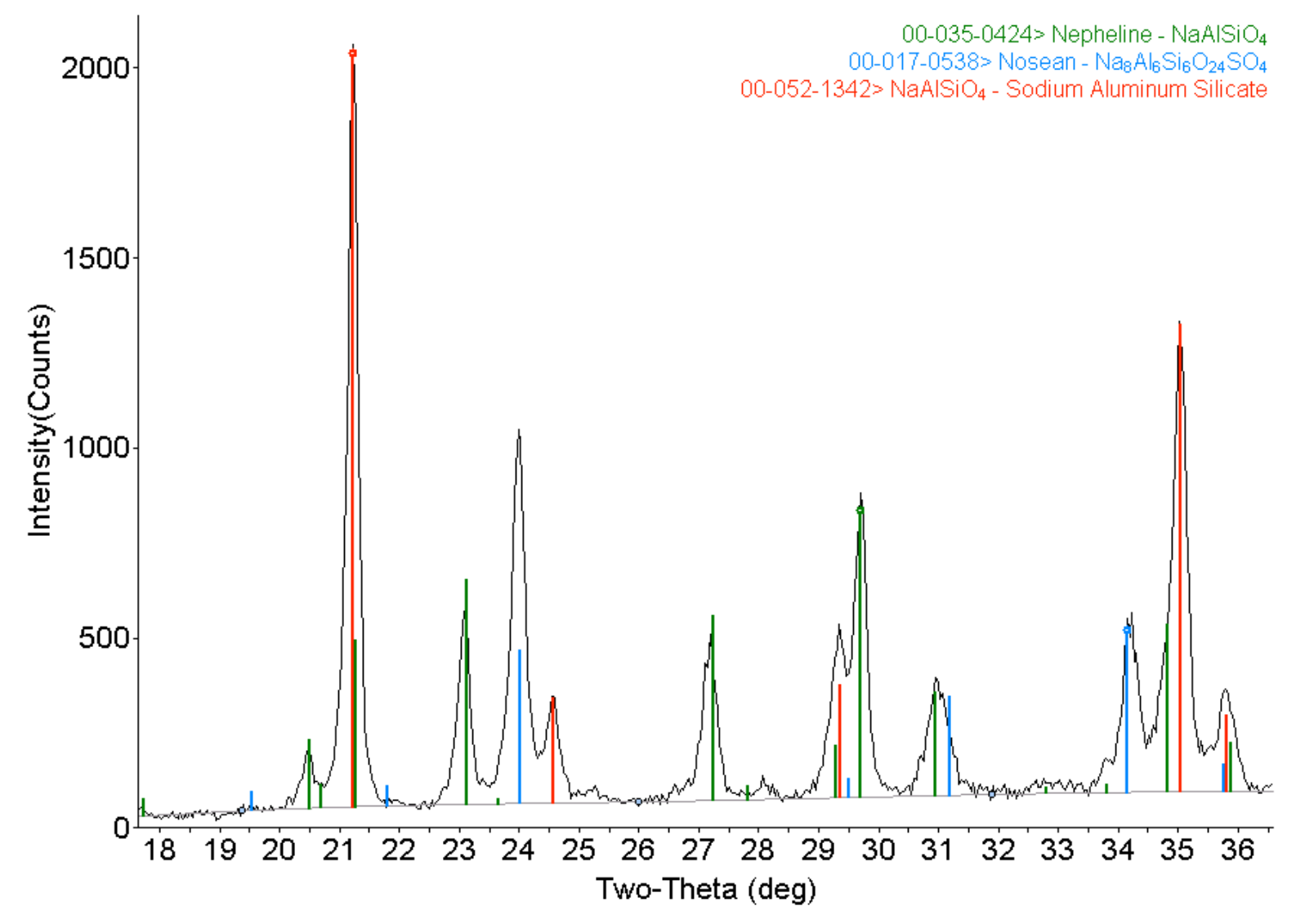

Figure S2. Enlarged region of diffraction pattern shown in fig S1. A combination of the three phases identified is necessary to account for all the observed diffraction peaks.

The $\mathrm{NaAlSiO}_{4}$ phase identified is a likely to be a polymorph of nepheline (and other $\mathrm{NaAlSiO}_{4}$ phases), but has different diffraction peaks and therefore a different crystal structure. The more detailed portion of the XRD pattern shown in Fig. S2 further illustrates how this $\mathrm{NaAlSiO}_{4}$ cannot be confused with nepheline. It is also distinct from other $\mathrm{NaAlSiO}_{4}$ phases (e.g. carnegieite) reported in the diffraction database.

Nayak and Kutty reported that the XRD pattern could be indexed using an orthorhombic unit cell, based on an earlier report (Edgar, 1964 Am. Miner. 49 1139) of what was believed to be "nepheline hydrate I". 
However, Nayak and Kutty did not observe all the peaks of the earlier report, and the tabulated patterns of the two publications are significantly different. We needed a full crystal structure in order to carry out the quantitative phase analysis from XRD described in the main body of the paper. In the absence of a pure specimen, we solved the structure from the FBSR "as-is" data shown above which contained a bigh proportion of the new phase.

Indexing of the peaks observed in the present study suggested a hexagonal unit cell, with $a=5.12 \AA$ and $c$ $=12.51 \AA$. Systematic absences were consistent with the space group $P 3_{1}$. After some investigation a likely candidate structure was constructed, starting from the observation that $\mathrm{SiO}_{4}$ tetrahedra can be arranged in hexagonal sheets with a 2-dimensional lattice spacing of $5.2 \AA$. Alternating $\mathrm{AlO}_{4}$ tetrahedra were substituted into these sheets which were stacked along the $c$ axis. The resulting structure contained cavities above the corner-sharing hexagons of $\mathrm{MO}_{4}$ tetrahedra suitable for placement of $\mathrm{Na}$. Positioning of $\mathrm{Na}$ in these spaces gave the correct $\mathrm{NaAlSiO}_{4}$ stoichiometry and an encouraging agreement between the observed and calculated diffraction patterns. Rietveld refinement of the structure was carried out using the same software (TOPAS v4.2) used for quantitative phase analysis, with $\mathrm{SiO}_{4}$ tetrahedra refined as rigid bodies.

The refinement gave a good fit to the experimental data, shown in Fig S3 below. Nosean and nepheline were modeled using the structures reported in Table 3 in the main paper and only scale factors and microstructural parameters were refined for these phases. The Bragg R-factor for the new NaAlSiO4 phase was $4.5 \%$. This, and the chemically sensible arrangement of $\mathrm{SiO}_{4} / \mathrm{AlO}_{4}$ tetrahedra, gave us confidence in the new proposed structure. 


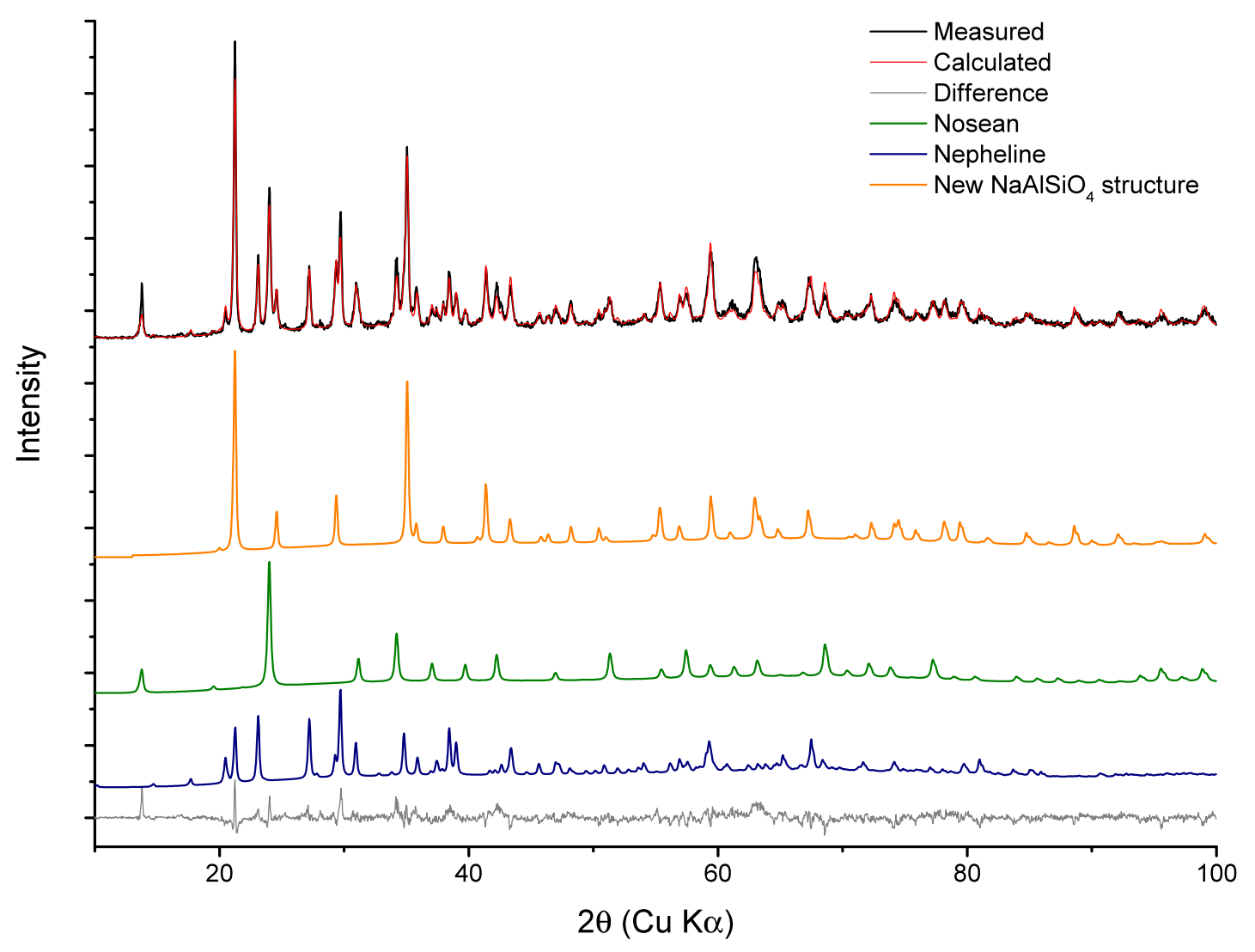

Figure S3. Comparison of observed (black) and calculated (red) XRD patterns after Rietveld refinement of new $\mathrm{NaAlSiO}_{4}$ phase. The contributions of the individual phases are shown below the observed/calculated patterns and the difference is shown at the bottom. 